\title{
LEVEL II SCOUR ANALYSIS FOR BRIDGE 33 (TUNBTH00450033) on TOWN HIGHWAY 45, crossing the FIRST BRANCH WHITE RIVER, TUNBRIDGE, VERMONT
}

Open-File Report 97-803

Prepared in cooperation with

VERMONT AGENCY OF TRANSPORTATION and

FEDERAL HIGHWAY ADMINISTRATION

U.S. Department of the Interior U.S. Geological Survey

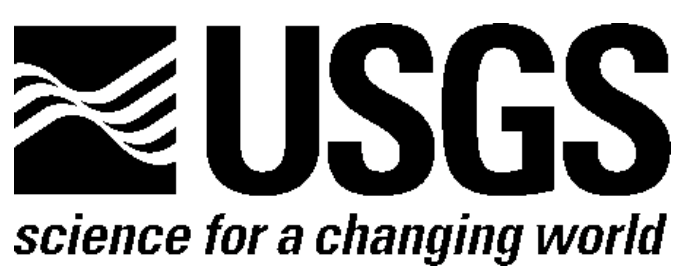




\section{LEVEL II SCOUR ANALYSIS FOR BRIDGE 33 (TUNBTH00450033) on TOWN HIGHWAY 45, crossing the FIRST BRANCH WHITE RIVER, TUNBRIDGE, VERMONT \\ By EMILY C. WILD and TIMOTHY SEVERANCE}

U.S. Geological Survey

Open-File Report 97-803

Prepared in cooperation with

VERMONT AGENCY OF TRANSPORTATION

and

FEDERAL HIGHWAY ADMINISTRATION 


\title{
U.S. DEPARTMENT OF THE INTERIOR BRUCE BABBITT, Secretary
}

\author{
U.S. GEOLOGICAL SURVEY \\ Mark Schaefer, Acting Director
}

For additional information write to:

District Chief

U.S. Geological Survey 361 Commerce Way

Pembroke, NH 03275-3718
Copies of this report may be purchased from:

U.S. Geological Survey

Branch of Information Services

Open-File Reports Unit

Box 25286

Denver, CO 80225-0286 


\section{CONTENTS}

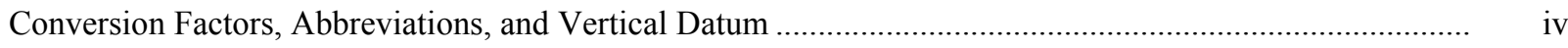

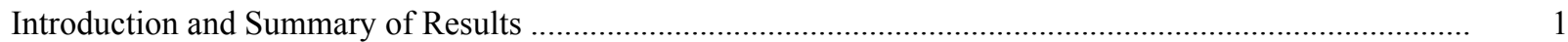

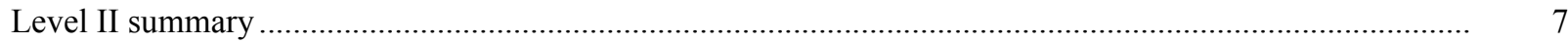

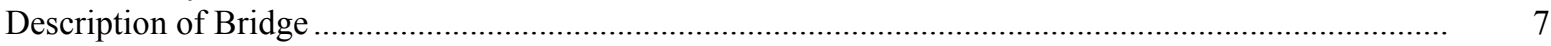

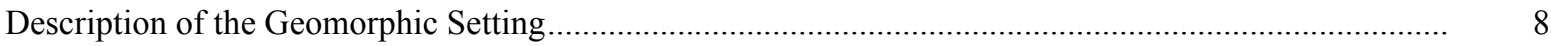

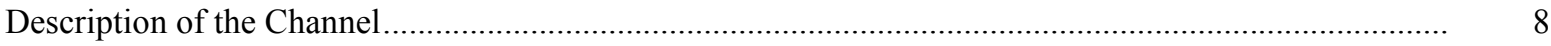

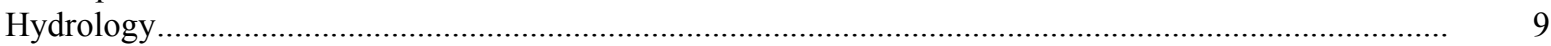

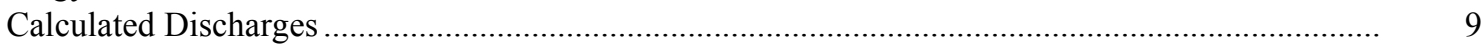

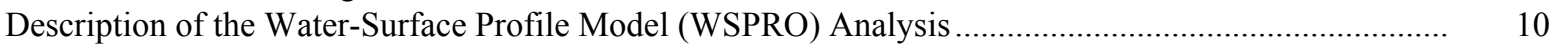

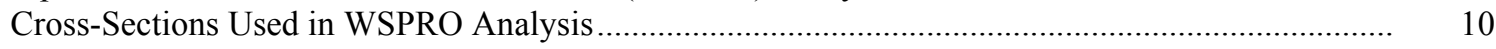

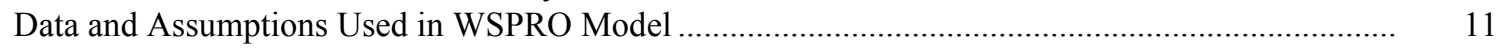

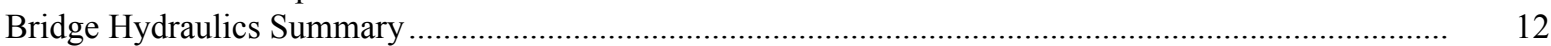

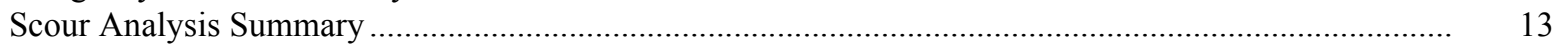

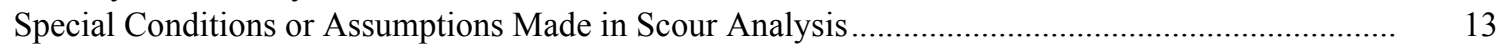

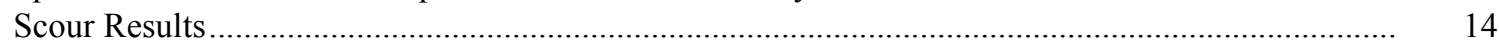

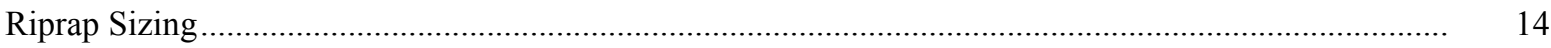

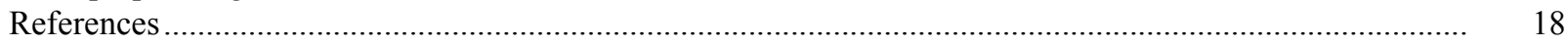

Appendices:

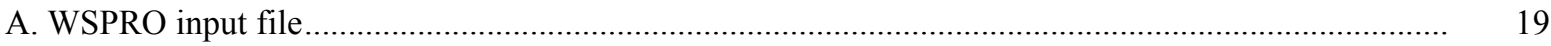

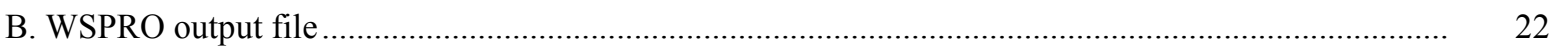

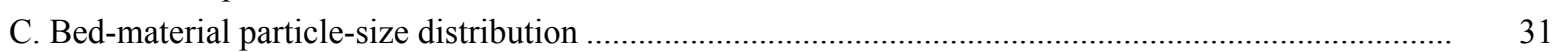

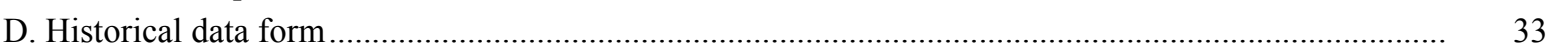

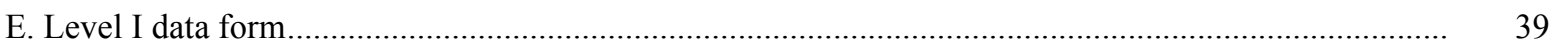

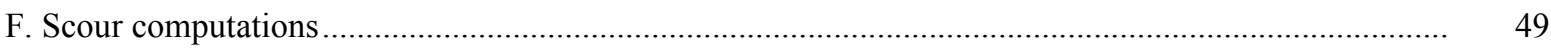

\section{FIGURES}

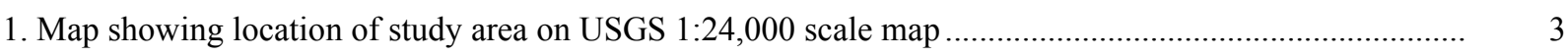

2. Map showing location of study area on Vermont Agency of Transportation town

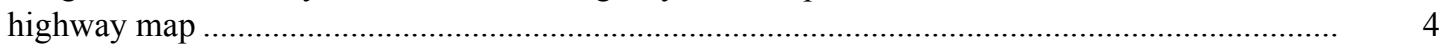

3. Structure TUNBTH00450033 viewed from upstream (October 18, 1995) .......................................... 5

4. Downstream channel viewed from structure TUNBTH00450033 (October 18, 1995)............................. 5

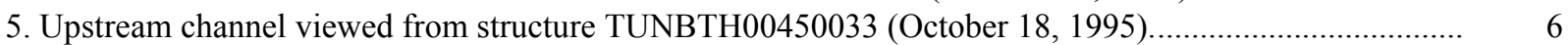

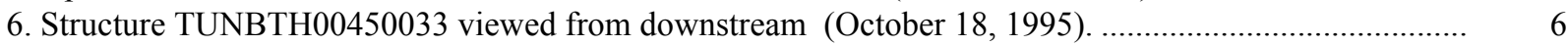

7. Water-surface profiles for the 100- and 500-year discharges at structure

TUNBTH00450033 on Town Highway 45, crossing the First Branch White River,

Tunbridge, Vermont.

8. Scour elevations for the 100- and 500-year discharges at structure

TUNBTH00450033 on Town Highway 45, crossing the First Branch White River,

Tunbridge, Vermont.

\section{TABLES}

1. Remaining footing/pile depth at abutments for the 100-year discharge at structure

TUNBTH00450033 on Town Highway 45, crossing the First Branch White River,

Tunbridge, Vermont.

2. Remaining footing/pile depth at abutments for the 500-year discharge at structure

TUNBTH00450033 on Town Highway 45, crossing the First Branch White River,

Tunbridge, Vermont. 


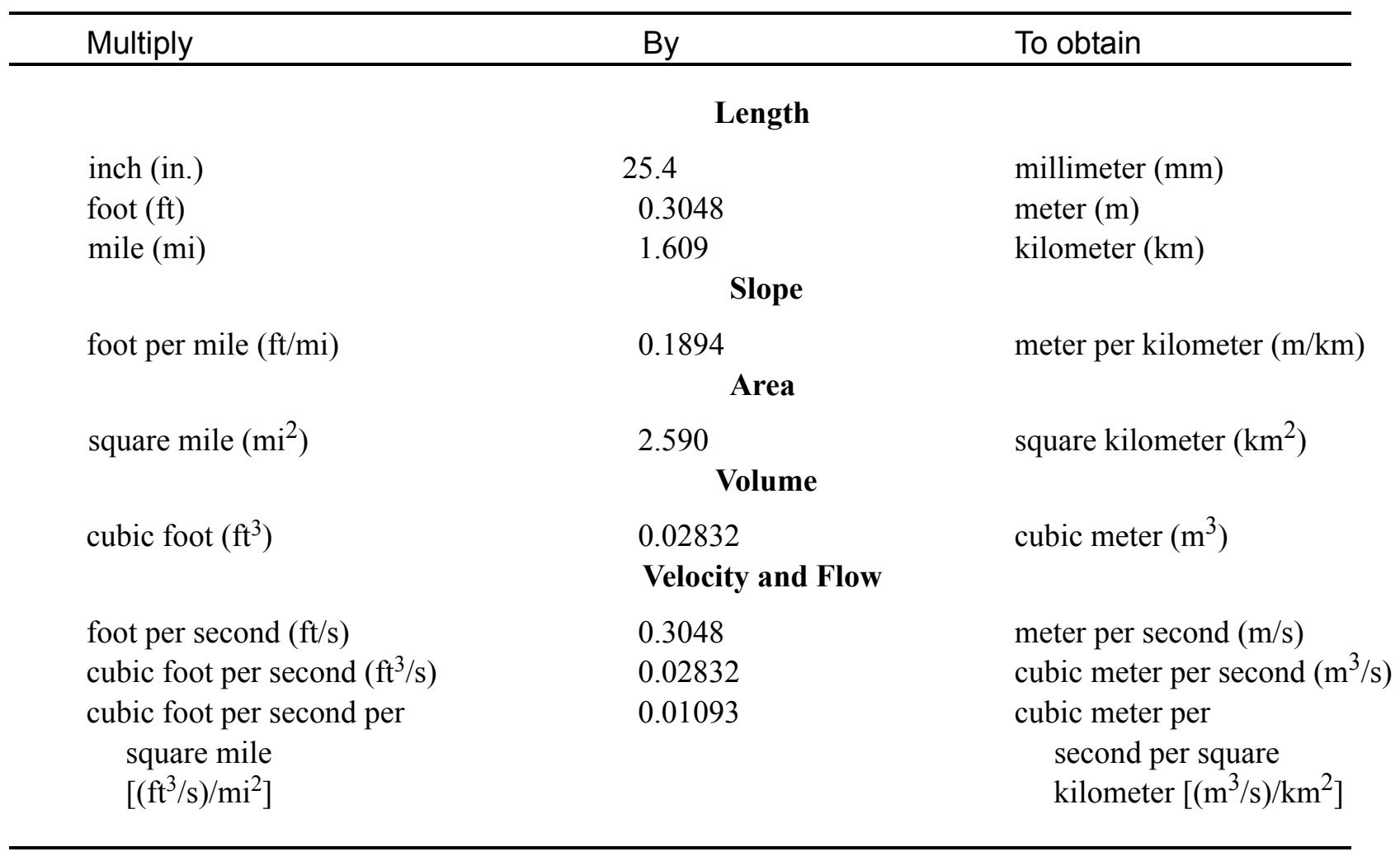

\section{OTHER ABBREVIATIONS}

$\begin{array}{lrlr}\mathrm{BF} & \text { bank full } & \text { LWW } & \text { left wingwall } \\ \mathrm{cfs} & \text { cubic feet per second } & \text { MC } & \text { main channel } \\ \mathrm{D}_{50} & \text { median diameter of bed material } & \text { RAB } & \text { right abutment } \\ \mathrm{DS} & \text { downstream } & \text { RABUT } & \text { face of right abutment } \\ \mathrm{elev} & \text { elevation } & \text { RB } & \text { right bank } \\ \mathrm{f} / \mathrm{p} & \text { flood plain } & \text { ROB } & \text { right overbank } \\ \mathrm{ft}^{2} & \text { square feet } & \text { RWW } & \text { right wingwall } \\ \mathrm{ft} / \mathrm{ft} & \text { feet per foot } & \text { TH } & \text { town highway } \\ \mathrm{JCT} & \text { junction } & \text { UB } & \text { under bridge } \\ \mathrm{LAB} & \text { left abutment } & \text { US } & \text { upstream } \\ \mathrm{LABUT} & \text { face of left abutment } & \text { USGS } & \text { United States Geological Survey } \\ \mathrm{LB} & \text { left bank } & \text { VTAOT Vermont Agency of Transportation } \\ \mathrm{LOB} & \text { left overbank } & \text { WSPRO } & \text { water-surface profile model }\end{array}$

In this report, the words "right" and "left" refer to directions that would be reported by an observer facing downstream. Sea level: In this report, "sea level" refers to the National Geodetic Vertical Datum of 1929-- a geodetic datum derived from a general adjustment of the first-order level nets of the United States and Canada, formerly called Sea Level Datum of 1929.

In the appendices, the above abbreviations may be combined. For example, USLB would represent upstream left bank. 


\title{
LEVEL II SCOUR ANALYSIS FOR BRIDGE 33 (TUNBTH00450033) ON TOWN HIGHWAY 45, CROSSING THE FIRST BRANCH WHITE RIVER, TUNBRIDGE, VERMONT
}

\author{
By Emily C. Wild and Timothy Severance
}

\section{INTRODUCTION AND SUMMARY OF RESULTS}

This report provides the results of a detailed Level II analysis of scour potential at structure TUNBTH00450033 on Town Highway 45 crossing the First Branch White River, Tunbridge, Vermont (figures 1-8). A Level II study is a basic engineering analysis of the site, including a quantitative analysis of stream stability and scour (U.S. Department of Transportation, 1993). Results of a Level I scour investigation also are included in Appendix E of this report. A Level I investigation provides a qualitative geomorphic characterization of the study site. Information on the bridge, gleaned from Vermont Agency of Transportation (VTAOT) files, was compiled prior to conducting Level I and Level II analyses and is found in Appendix D.

The site is in the New England Upland section of the New England physiographic province in central Vermont. The 86.4- $\mathrm{mi}^{2}$ drainage area is in a predominantly rural and forested basin. In the vicinity of the study site, the surface cover is pasture upstream and downstream of the bridge, while woody vegetation sparsely covers the immediate banks.

In the study area, the First Branch White River has an incised, sinuous channel with a slope of approximately $0.003 \mathrm{ft} / \mathrm{ft}$, an average channel top width of $68 \mathrm{ft}$ and an average bank height of $7 \mathrm{ft}$. The channel bed material ranges from sand to gravel with a median grain size $\left(\mathrm{D}_{50}\right)$ of $27.1 \mathrm{~mm}(0.089 \mathrm{ft})$. The geomorphic assessment at the time of the Level I and Level II site visit on October 18, 1995, indicated that the reach was laterally unstable due to a cut-bank present on the upstream right bank and a wide channel bar in the upstream reach.

The Town Highway 45 crossing of the First Branch White River is a 67-ft-long, one-lane bridge consisting of one 54-foot timber thru-truss span (Vermont Agency of Transportation, written communication, March 23,1995). The opening length of the structure parallel to the bridge face is $53.5 \mathrm{ft}$. The bridge is supported on the right by a vertical, concrete abutment with an upstream wingwall, and on the left by a vertical, stone abutment. The channel is skewed approximately 20 degrees to the opening while the computed opening-skew-toroadway is 10 degrees. 
A scour hole $1.5 \mathrm{ft}$ deeper than the mean thalweg depth was observed along the right abutment during the Level I assessment. Scour countermeasures at the site include type-1 stone fill (less than 12 inches diameter) along the upstream right wingwall, type-2 stone fill (less than 36 inches diameter) along the right abutment, and type-3 stone fill (less than 48 inches diameter) along the upstream right bank. Additional details describing conditions at the site are included in the Level II Summary and Appendices D and E.

Scour depths and recommended rock rip-rap sizes were computed using the general guidelines described in Hydraulic Engineering Circular 18 (Richardson and others, 1995) for the 100- and 500-year discharges. In addition, the incipient roadway-overtopping discharge was determined and analyzed as another potential worst-case scour scenario. Total scour at a highway crossing is comprised of three components: 1) long-term streambed degradation; 2) contraction scour (due to accelerated flow caused by a reduction in flow area at a bridge) and; 3) local scour (caused by accelerated flow around piers and abutments). Total scour is the sum of the three components. Equations are available to compute depths for contraction and local scour and a summary of the results of these computations follows.

Contraction scour for all modelled flows ranged from 0.0 to $3.0 \mathrm{ft}$. The worst-case contraction scour occurred at the 500-year discharge. Left abutment scour ranged from 12.8 to $31.0 \mathrm{ft}$. Right abutment scour ranged from 9.8 to $19.0 \mathrm{ft}$. The worst-case left and right abutment scour occurred at the 500-year discharge. Additional information on scour depths and depths to armoring are included in the section titled "Scour Results". Scouredstreambed elevations, based on the calculated scour depths, are presented in Tables 1 and 2. A cross-section of the scour computed at the bridge is presented in Figure 8. Scour depths were calculated assuming an infinite depth of erosive material and a homogeneous particlesize distribution.

It is generally accepted that the Froehlich equation (abutment scour) gives "excessively conservative estimates of scour depths" (Richardson and others, 1995, p. 47). Usually, computed scour depths are evaluated in combination with other information including (but not limited to) historical performance during flood events, the geomorphic stability assessment, existing scour protection measures, and the results of the hydraulic analyses. Therefore, scour depths adopted by VTAOT may differ from the computed values documented herein. 


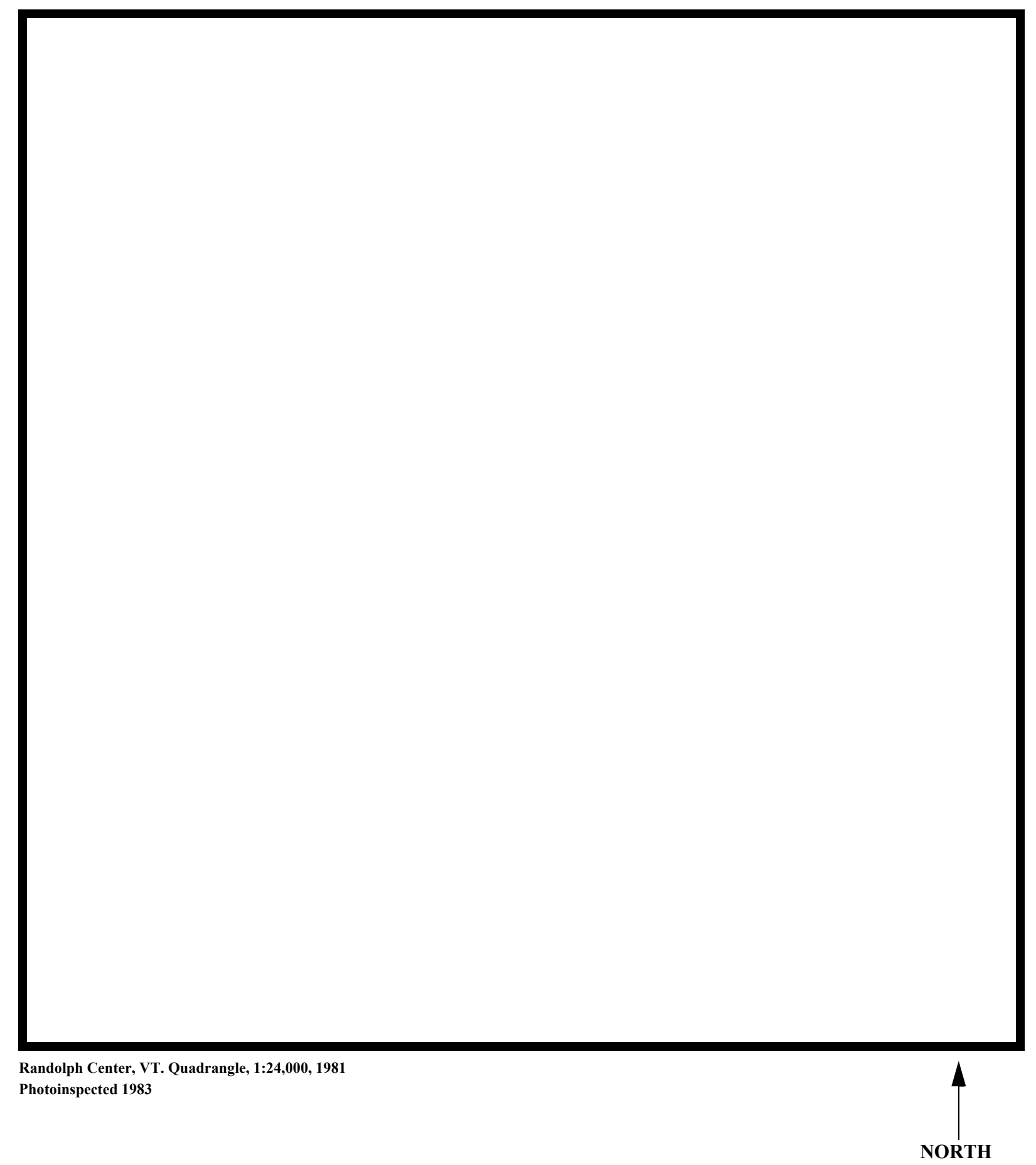

Figure 1. Location of study area on USGS 1:24,000 scale map. 
Figure 2. Location of study area on Vermont Agency of Transportation town highway map. 

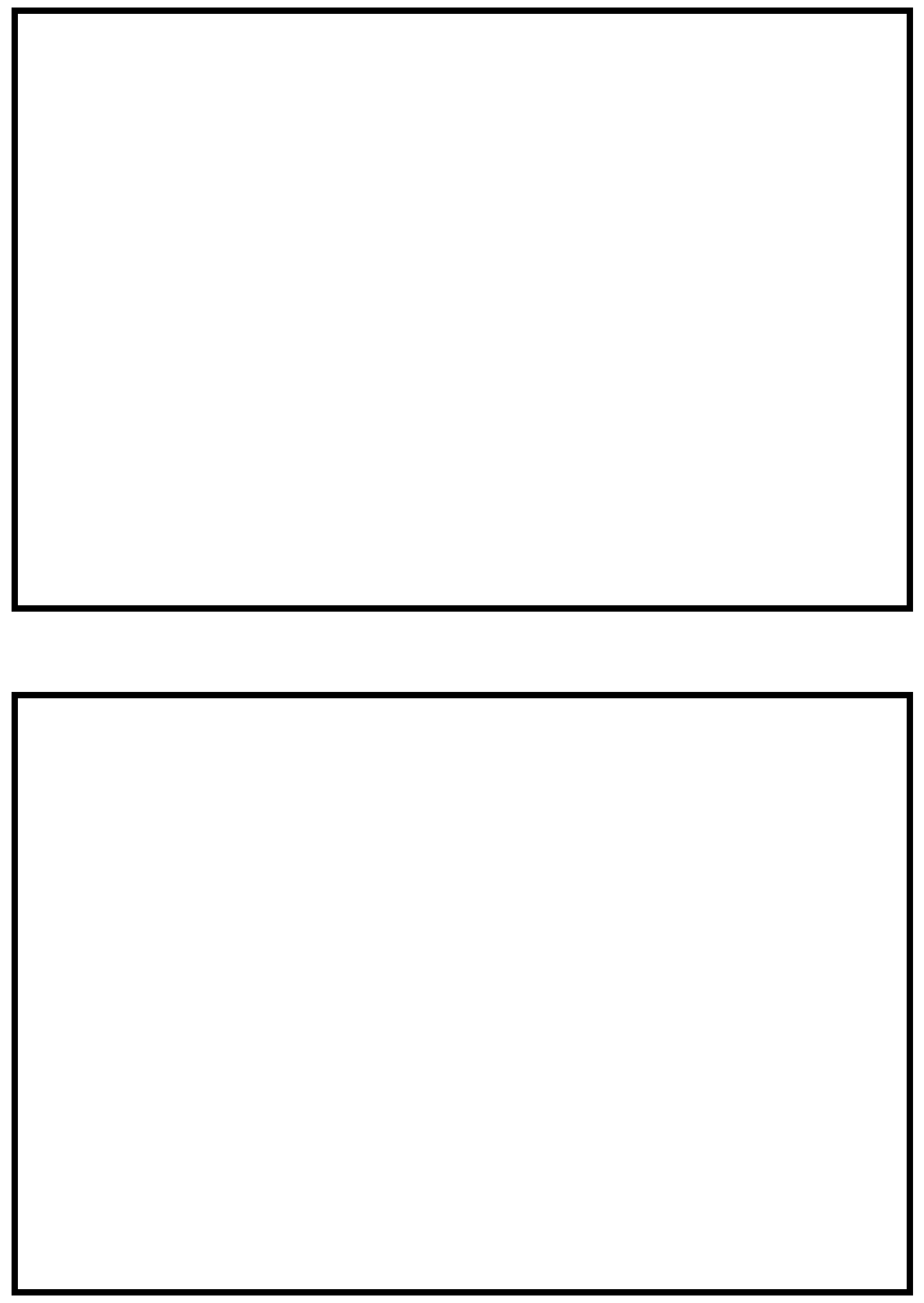

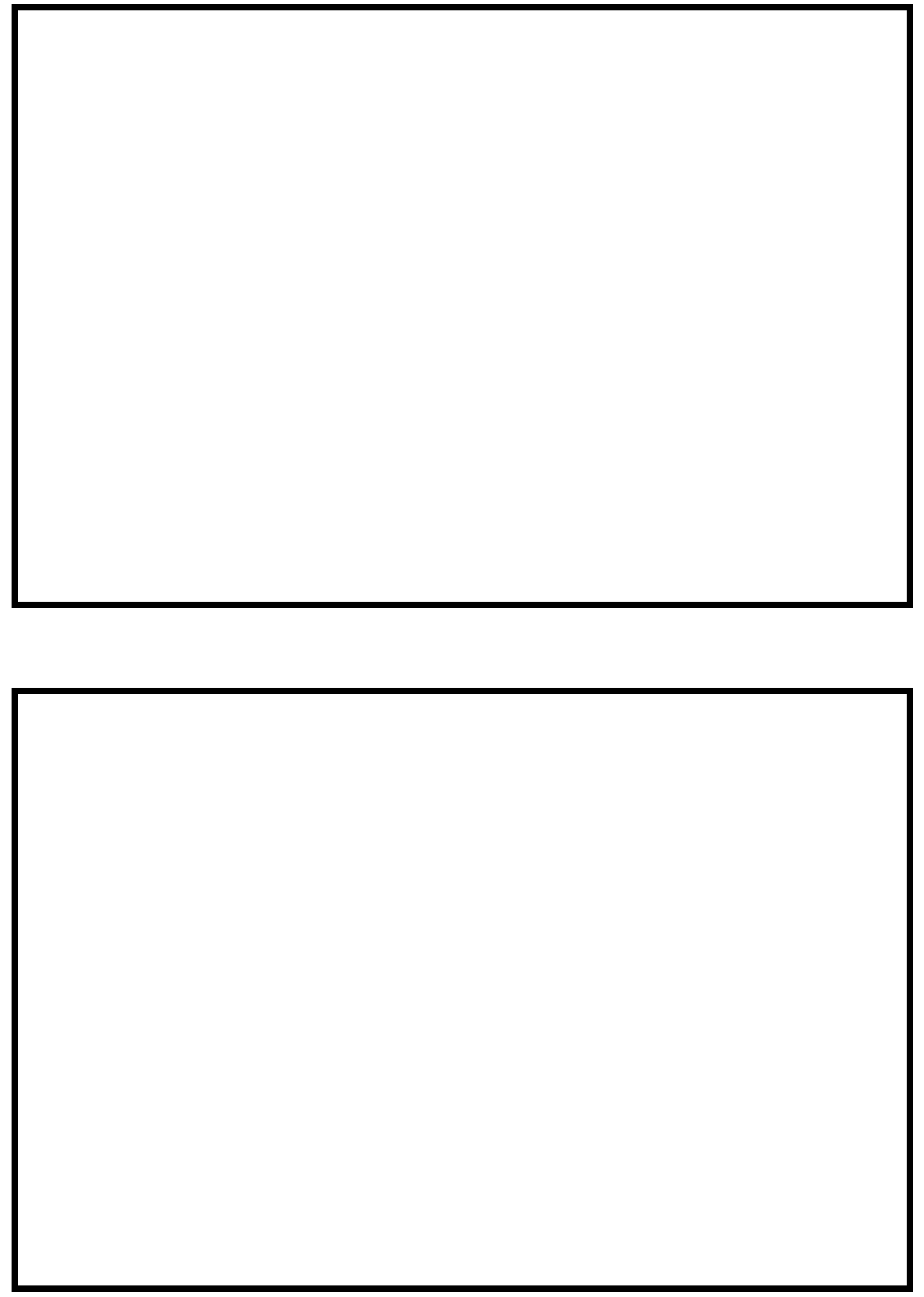


\section{LEVEL II SUMMARY}

\begin{tabular}{llllll} 
& Structure Number & TUNBTH00450033 & & \multicolumn{3}{c}{ First Branch White River } \\
Stream & & & \\
County & Orange & Road & TH45 & District & 4
\end{tabular}

\section{Description of Bridge}

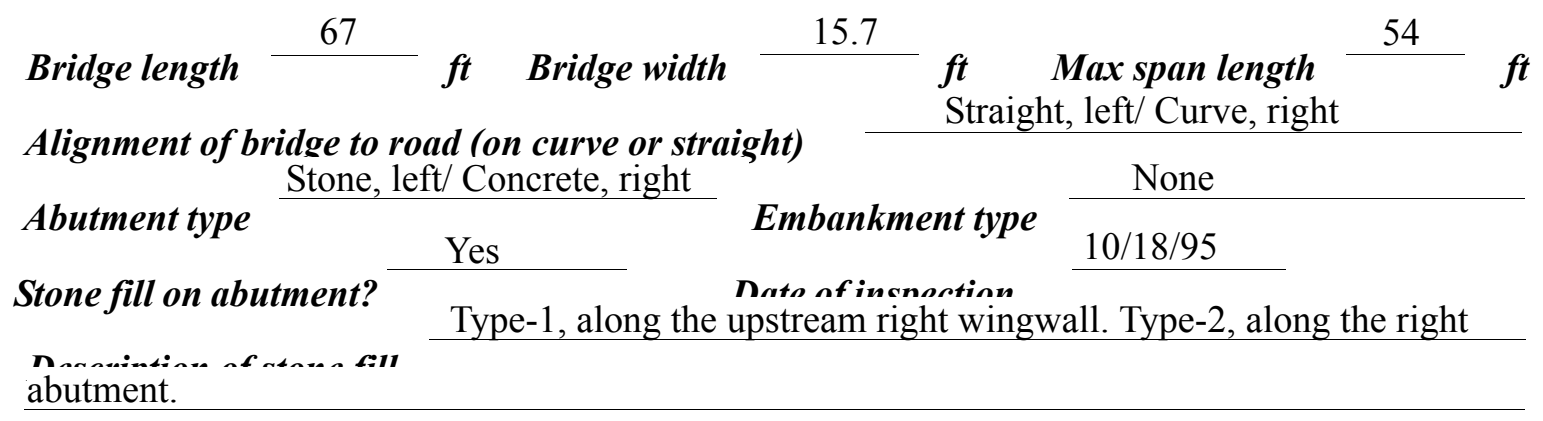

The left abutment is vertical, placed stone. The right abutment and upstream right wingwall are vertical, concrete. There is a one and a half ft deep scour hole in front of the right abutment.

Yes 20

Is bridge skewed to flood flow according to Yes 'survey? Angle

There is a mild_channel bend in the upstream reach. The scour hole has developed in the lo, cation where the flow impacts the right abutment.

Debris accumulation on bridge at time of Level I or Level II site visit:

\begin{tabular}{|c|c|c|c|}
\hline & $\begin{array}{c}\text { Date of insmortion } \\
10 / 18 / 95 \\
\end{array}$ & $\begin{array}{l}\text { Percent of almmanl } \\
\text { blocked inortzontatly }\end{array}$ & $\begin{array}{l}\text { Percent of } 0 \\
\text { blocked verticatty }\end{array}$ \\
\hline & $10 / 18 / 95$ & 0 & 0 \\
\hline Level II & Low. Ther & me debris along the hi & \\
\hline
\end{tabular}

Potential for debris

No features were observed during the 10/18/95 site visit.

Doscriho anv, fonturos noar ar at tho hridoo that mav, affort flou, (includo ahsorvation dato) 


\section{Description of the Geomorphic Setting}

General topography The channel is located within a narrow, flat to slightly irregular flood plain with moderately sloped valley walls on both sides.

Geomorphic conditions at bridge site: downstream (DS), upstream (US)

Date of inspection $\quad 10 / 18 / 95$

DS left: $\quad$ Steep channel bank and moderately sloped overbank.

DS right: $\quad$ Steep channel bank and steep overbank.

US left: $\quad$ Steep channel bank and moderately sloped overbank.

US right: $\quad$ Steep channel bank and steep overbank.

\section{Description of the Channel}

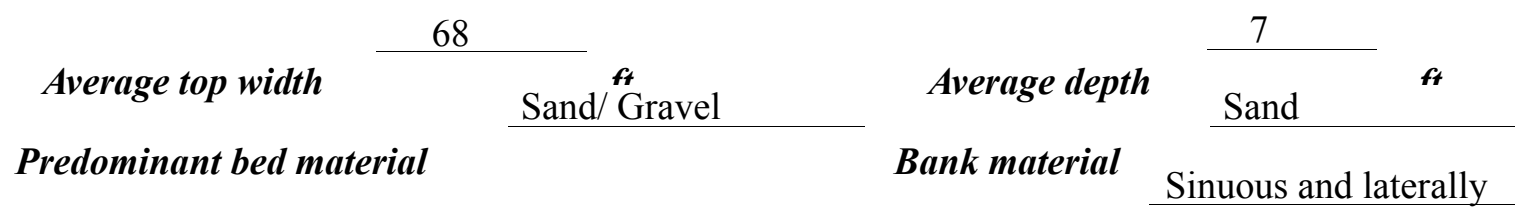

unstable with alluvial channel boundaries and a narrow flood plain."

$10 / 18 / 95$

Vegetative co ${ }^{1}$ Pasture with some trees along the immediate bank.

DS left: $\quad$ Pasture with trees and Town Highway 45 along the immediate bank.

DS right: $\quad$ Pasture with some trees along the immediate banks.

US left: $\quad$ Pasture with trees and Town Highway 45 along the immediate bank.

US right: $\quad$ No

Do banks appear stable? The 10/18/95 site assessment noted that the banks are laterally wan danstable as shown by bank slip failure and bank erosion.

18/95 noted no obstructions.

Describe any obstructions in channel and date of observation. 


\section{Hydrology}

Drainage area $\quad 86.4 \mathrm{mi}^{2}$

Percentage of drainage area in physiographic provinces: (approximate)

Physiographic province/section New England/ New England Upland
Percent of drainage area 100
Is drainage area considered rural or urban?
Rural urbanization: None
Describe any significant

\section{Calculated Discharges $\quad 20,440$ \\ 13,930 $\mathrm{ft}^{3} / \mathrm{s}$ \\ Q500 $\quad \mathrm{ft}^{3} / \mathrm{s}$}

The 100- and 500-year discharges are based on a

drainage area relationship [(86.4/96)exp 0.7] with Flood Insurance Study discharge values at the Royalton/Tunbridge corporate limits (Federal Emergency Management Agency, 1989). The Royalton/Tunbridge corporate limits is downstream of this site on the First Branch White River. 


\section{Description of the Water-Surface Profile Model (WSPRO) Analysis}

Datum for WSPRO analysis (USGS survey, sea level, VTAOT plans)

USGS survey

Datum tie between USGS survey and VTAOT plans

None

Description of reference marks used to determine USGS datum. $\quad$ RM1 is a nail in a

telephone pole on the upstream left overbank, 184 feet from the left abutment (elev. $503.65 \mathrm{ft}$,

arbitrary survey datum). RM2 is a nail in a telephone pole on the right overbank, 15 feet

upstream (elev. $511.56 \mathrm{ft}$, arbitrary survey datum). $\mathrm{RM} 3$ is a chiseled $\mathrm{X}$ in the asphalt, on the

downstream side of the road sixteen feet from the left abutment (elev. $504.16 \mathrm{ft}$, arbitrary survey

datum).

\begin{tabular}{cccl}
\hline${ }^{1}$ Cross-section & $\begin{array}{c}\text { Section } \\
\text { Reference } \\
\text { Distance } \\
\text { (SRD) } \text { in feet }\end{array}$ & $\begin{array}{c}{ }^{2} \text { Cross-section } \\
\text { development }\end{array}$ & \multicolumn{1}{c}{ Comments } \\
\hline EXIT1 & -58 & 1 & $\begin{array}{l}\text { Exit section } \\
\text { Downstream Full-valley } \\
\text { section (Templated from } \\
\text { EXIT1) }\end{array}$ \\
BRIDG & 0 & 2 & $\begin{array}{l}\text { Bridge section } \\
\text { Road Grade section }\end{array}$ \\
RDWAY & 0 & 1 & $\begin{array}{l}\text { Modelled Approach sec- } \\
\text { tion (Templated from } \\
\text { APPR1 }\end{array}$ \\
& 10 & 1 & $\begin{array}{l}\text { APTEM) } \\
\text { Approach section as sur- } \\
\text { veyed (Used as a tem- } \\
\text { plate) }\end{array}$ \\
\hline
\end{tabular}

${ }^{1}$ For location of cross-sections see plan-view sketch included with Level I field form, Appendix E. 


\section{Data and Assumptions Used in WSPRO Model}

Hydraulic analyses of the reach were done by use of the Federal Highway Administration's WSPRO step-backwater computer program (Shearman and others, 1986, and Shearman, 1990). The analyses reported herein reflect conditions existing at the site at the time of the study. Furthermore, in the development of the model it was necessary to assume no accumulation of debris or ice at the site. Results of the hydraulic model are presented in the Bridge Hydraulic Summary, Appendix B, and figure 7.

Channel roughness factors (Manning's “ $n$ ”) used in the hydraulic model were estimated using field inspections at each cross section following the general guidelines described by Arcement and Schneider (1989). Final adjustments to the values were made during the modelling of the reach. Channel " $\mathrm{n}$ " values for the reach ranged from 0.030 to 0.040 , and overbank " $\mathrm{n}$ " values ranged from 0.035 to 0.050 .

Normal depth at the exit section (EXIT1) was assumed as the starting water surface. This depth was computed by use of the slope-conveyance method outlined in the user's manual for WSPRO (Shearman, 1990). The slope used was $0.0027 \mathrm{ft} / \mathrm{ft}$ which was calculated from slopes surveyed downstream.

The surveyed approach section (APTEM) was moved along the approach channel slope $(0.0004 \mathrm{ft} / \mathrm{ft})$ to establish the modelled approach section (APPR1), one bridge length upstream of the upstream face as recommended by Shearman and others (1986). This location also provides a consistent method for determining scour variables. 


\section{Bridge Hydraulics Summary}

\begin{tabular}{lll} 
Average bridge embankment elevation & 505.3 \\
\cline { 3 - 3 } Average low steel elevation & 502.8 & $\boldsymbol{f t}$
\end{tabular}

100-year discharge $\quad 13,930 \quad \mathrm{ft}^{3} / \mathrm{s}$

Water-surface elevation in bridge opening $\quad 502.9 \quad f t$

Road overtopping? ___ Y Discharge over road _ـ 9,730 $\mathrm{ft}^{3} / \mathrm{s}$

Area of flow in bridge opening $\quad 635 \quad \mathrm{ft}^{2}$

Average velocity in bridge opening $\quad 6.6 \mathrm{ft} / \mathrm{s}$

Maximum WSPRO tube velocity at bridge $\quad 7.9 \mathrm{ft} / \mathrm{s}$

Water-surface elevation at Approach section with bridge

Water-surface elevation at Approach section without bridge

504.2

Amount of backwater caused by bridge

1.7 it

\section{5}

500-year discharge $\quad 20,440 \quad \mathrm{ft}^{3} / \mathrm{s}$

Water-surface elevation in bridge opening

$502.9 f t$

Road overtopping? ___ Y Discharge over road __ 14,780 $\mathrm{ft}^{3} / \mathrm{s}$

Area of flow in bridge opening $\quad 635 \quad \mathrm{ft}^{2}$

Average velocity in bridge opening $\quad 9.2 \mathrm{ft} / \mathrm{s}$

Maximum WSPRO tube velocity at bridge 11.0 /s

Water-surface elevation at Approach section with bridge

Water-surface elevation at Approach section without bridge

Amount of backwater caused by bridge 1.5 , $t$

505.3

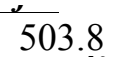

Incipient overtopping discharge $\quad 3,740 \quad \mathrm{ft}^{3} / \mathrm{s}$

Water-surface elevation in bridge opening $498.4 \quad t$

Area of flow in bridge opening

$408 \boldsymbol{f t}^{2}$

Average velocity in bridge opening $\quad 9.2 \quad \mathrm{ft} / \mathrm{s}$

Maximum WSPRO tube velocity at bridge $11.4 \mathrm{ft} / \mathrm{s}$

Water-surface elevation at Approach section with bridge

499.2

Water-surface elevation at Approach section without bridge

499.1 Amount of backwater caused by bridge

0.1 . $t$ 


\section{Scour Analysis Summary}

\section{Special Conditions or Assumptions Made in Scour Analysis}

Scour depths were computed using the general guidelines described in Hydraulic Engineering Circular 18 (Richardson and others, 1995). Scour depths were calculated assuming an infinite depth of erosive material and a homogeneous particle-size distribution. The results of the 100-year and 500-year scour analysis are presented in tables 1 and 2 and a graph of the scour depths is presented in figure 8 .

Contraction scour for the 100-year and incipient roadway-overtopping discharges was computed by use of the Laursen clear-water contraction scour equation (Richardson and others, 1995, p. 32, equation 20). At this site, the 500-year discharge resulted in submerged orifice flow. Contraction scour at bridges with orifice flow is best estimated by use of the Chang pressure-flow scour equation (oral communication, J. Sterling Jones, October 4, 1996). Thus, contraction scour for the 500-year discharge was computed by use of the Chang equation (Richardson and others, 1995, p. 145-146). For comparison, contraction scour for the 500-year discharge, which resulted in orifice flow, was also computed by use of the Laursen clear-water contraction scour equation and the Umbrell pressure-flow equation (Richardson and others, 1995, p. 144) and presented in Appendix F. The streambed armoring depths computed suggest that armoring will not limit the depth of contraction scour.

Abutment scour was computed by use of the Froehlich equation (Richardson and others, 1995, p. 48, equation 28). Variables for the Froehlich equation include the Froude number of the flow approaching the embankments, the length of the embankment blocking flow, and the depth of flow approaching the embankment less any roadway overtopping. 


\section{Scour Results}

100-yr discharge 500-yr discharge

(Scour depths in feet)

Main channel

Live-bed scour

Clear-water scour

Depth to armoring

Left overbank

Right overbank

Local scour:

Abutment scour

Left abutment

Right abutment

Pier scour

Pier 1

Pier 2

Pier 3

\section{Abutments:}

Left abutment

Right abutment

Piers:

Pier 1

Pier 2

Incipient overtopping discharge
31.0

19.0
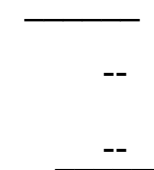

$--$

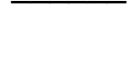

12.8

$9.8-$
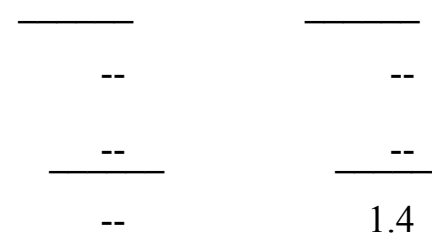

1.4

\section{Riprap Sizing}

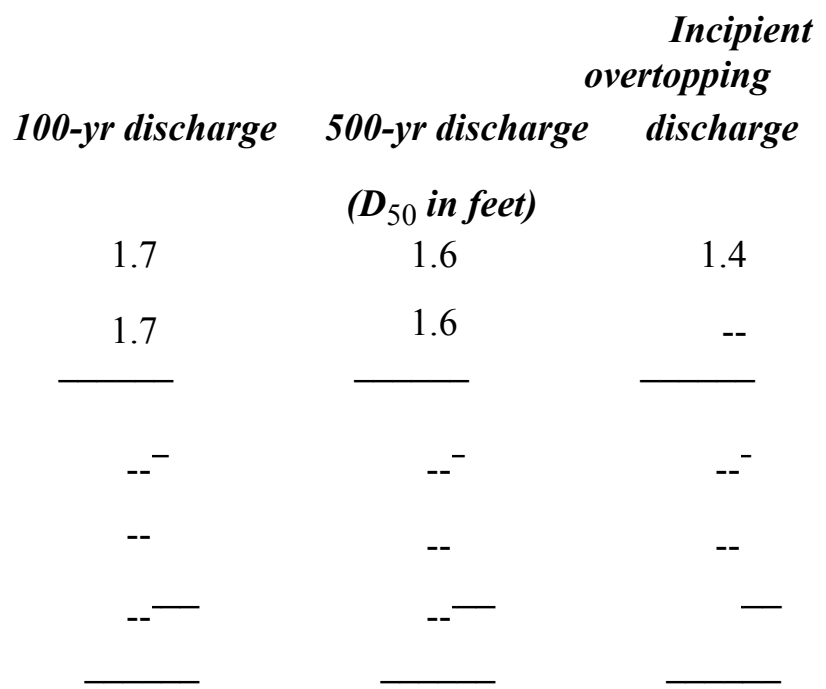




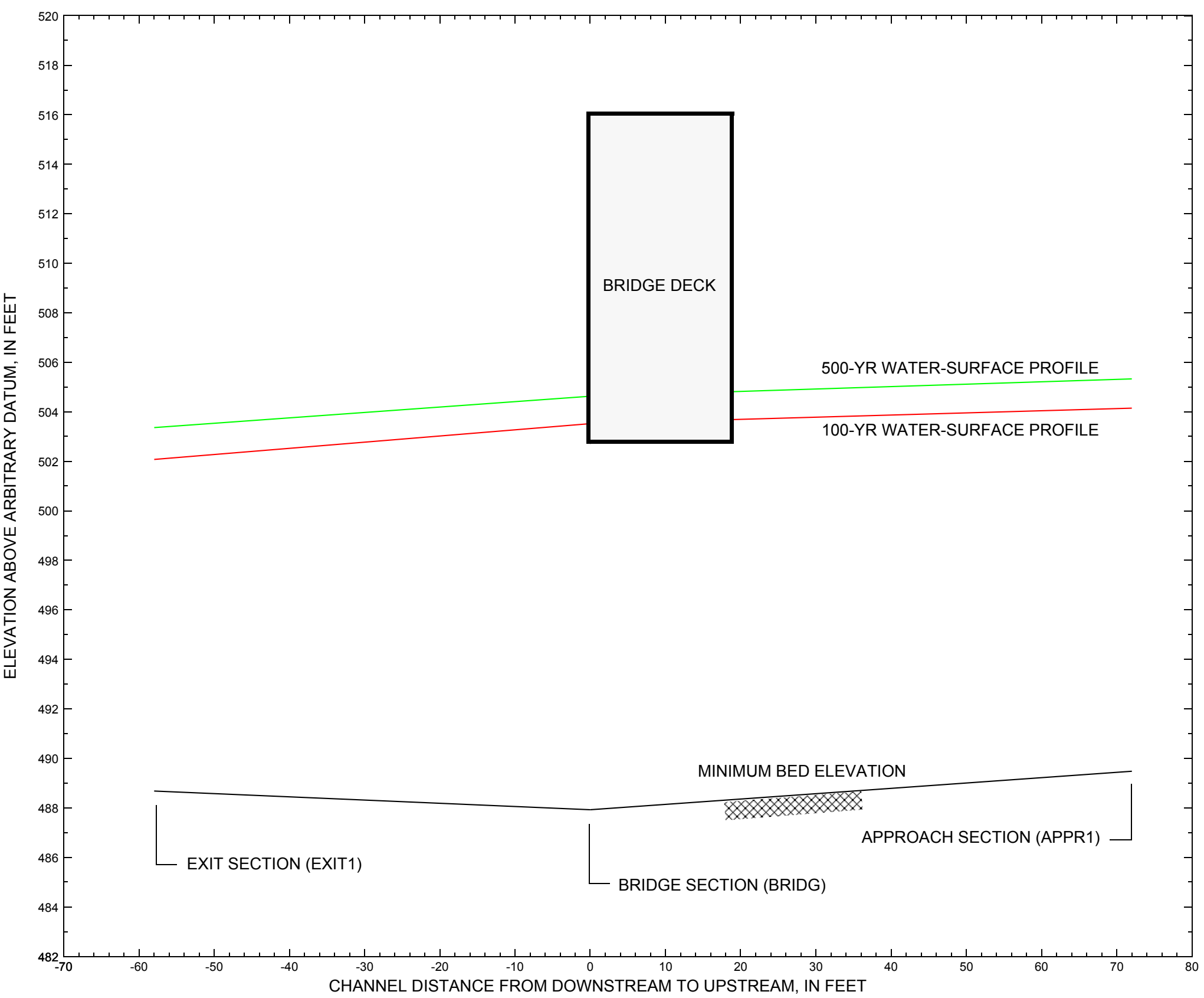

Figure 7. Water-surface profiles for the 100- and 500-yr discharges at structure TUNBTH00450033 on Town Highway 45, crossing the First Branch White River, Tunbridge, Vermont. 


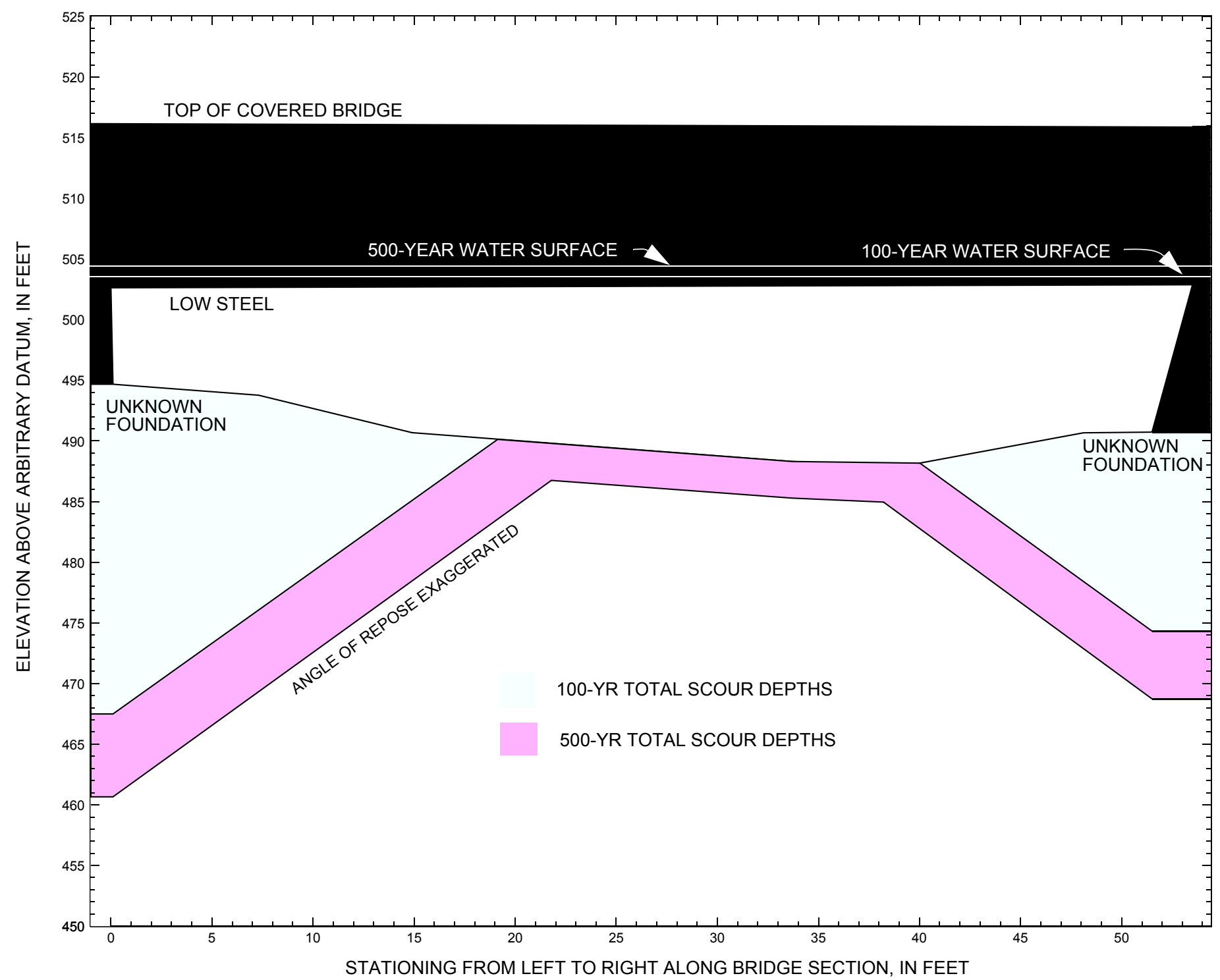

Figure 8. Scour elevations for the 100-yr and 500-yr discharges at structure TUNBTH00450033 on Town Highway 45, crossing the First Branch White River, Tunbridge, Vermont. 
Table 1. Remaining footing/pile depth at abutments for the 100-year discharge at structure TUNBTH00450033 on Town Highway 45, crossing the First Branch White River, Tunbridge, Vermont.

[VTAOT, Vermont Agency of Transportation; --,no data]

\begin{tabular}{|c|c|c|c|c|c|c|c|c|c|c|c|}
\hline Description & Station $^{1}$ & $\begin{array}{l}\text { VTAOT } \\
\text { minimum } \\
\text { low-chord } \\
\text { elevation } \\
\text { (feet) }\end{array}$ & $\begin{array}{l}\text { Surveyed } \\
\text { minimum } \\
\text { low-chord } \\
\text { elevation }{ }^{2} \\
\text { (feet) }\end{array}$ & $\begin{array}{c}\text { Bottom of } \\
\text { footing/pile } \\
\text { elevation }{ }^{2} \\
\text { (feet) }\end{array}$ & $\begin{array}{c}\text { Channel } \\
\text { elevation at } \\
\text { abutment/ } \\
\text { pier }^{2} \\
\text { (feet) }\end{array}$ & $\begin{array}{l}\text { Contraction } \\
\text { scour depth } \\
\text { (feet) }\end{array}$ & $\begin{array}{l}\text { Abutment } \\
\text { scour } \\
\text { depth } \\
\text { (feet) }\end{array}$ & $\begin{array}{l}\text { Pier } \\
\text { scour } \\
\text { depth } \\
\text { (feet) }\end{array}$ & $\begin{array}{l}\text { Depth of } \\
\text { total scour } \\
\text { (feet) }\end{array}$ & $\begin{array}{c}\text { Elevation of } \\
\text { scour }^{2} \\
\text { (feet) }\end{array}$ & $\begin{array}{c}\text { Remaining } \\
\text { footing/pile } \\
\text { depth } \\
\text { (feet) }\end{array}$ \\
\hline \multicolumn{12}{|c|}{100 -yr. discharge is 13,930 cubic-feet per second } \\
\hline Left abutment & 0.0 & -- & 502.6 & -- & 494.7 & 0.0 & 27.2 & -- & 27.2 & 467.5 & -- \\
\hline Right abutment & 53.5 & -- & 502.9 & -- & 490.7 & 0.0 & 16.4 & -- & 16.4 & 474.3 & -- \\
\hline
\end{tabular}

1.Measured along the face of the most constricting side of the bridge.

2.Arbitrary datum for this study.

Table 2. Remaining footing/pile depth at abutments for the 500-year discharge at structure TUNBTH00450033 on Town Highway 45, crossing the First Branch White River, Tunbridge, Vermont.

[VTAOT, Vermont Agency of Transportation; --, no data]

\begin{tabular}{|c|c|c|c|c|c|c|c|c|c|c|c|}
\hline Description & Station $^{1}$ & $\begin{array}{l}\text { VTAOT } \\
\text { minimum } \\
\text { low-chord } \\
\text { elevation } \\
\text { (feet) }\end{array}$ & $\begin{array}{l}\text { Surveyed } \\
\text { minimum } \\
\text { low-chord } \\
\text { elevation } \\
\text { (feet) }\end{array}$ & $\begin{array}{c}\text { Bottom of } \\
\text { footing/pile } \\
\text { elevation } \\
\text { (feet) }\end{array}$ & $\begin{array}{c}\text { Channel } \\
\text { elevation at } \\
\text { abutment/ } \\
\text { pier }^{2} \\
\text { (feet) }\end{array}$ & $\begin{array}{l}\text { Contraction } \\
\text { scour depth } \\
\text { (feet) }\end{array}$ & $\begin{array}{l}\text { Abutment } \\
\text { scour } \\
\text { depth } \\
\text { (feet) }\end{array}$ & $\begin{array}{l}\text { Pier } \\
\text { scour } \\
\text { depth } \\
\text { (feet) }\end{array}$ & $\begin{array}{l}\text { Depth of } \\
\text { total scour } \\
\text { (feet) }\end{array}$ & $\begin{array}{c}\text { Elevation of } \\
\text { scour }^{2} \\
\text { (feet) }\end{array}$ & $\begin{array}{c}\text { Remaining } \\
\text { footing/pile } \\
\text { depth } \\
\text { (feet) }\end{array}$ \\
\hline \multicolumn{12}{|c|}{500 -yr. discharge is 20,440 cubic-feet per second } \\
\hline Left abutment & 0.0 & -- & 502.6 & -- & 494.7 & 3.0 & 31.0 & -- & 34.0 & 460.7 & -- \\
\hline Right abutment & 53.5 & -- & 502.9 & -- & 490.7 & 3.0 & 19.0 & -- & 22.0 & 468.7 & -- \\
\hline
\end{tabular}

1.Measured along the face of the most constricting side of the bridge.

2.Arbitrary datum for this study. 


\section{SELECTED REFERENCES}

Arcement, G.J., Jr., and Schneider, V.R., 1989, Guide for selecting Manning's roughness coefficients for natural channels and flood plains:

U.S. Geological Survey Water-Supply Paper 2339, 38 p.

Barnes, H.H., Jr., 1967, Roughness characteristics of natural channels: U.S. Geological Survey Water-Supply Paper 1849,213 p.

Benson, M. A., 1962, Factors Influencing the Occurrence of Floods in a Humid Region of Diverse Terrain: U.S. Geological Survey WaterSupply Paper 1580-B, 64 p.

Brown, S.A. and Clyde, E.S., 1989, Design of riprap revetment: Federal Highway Administration Hydraulic Engineering Circular No. 11, Publication FHWA-IP-89-016, 156 p.

Federal Highway Administration, 1983, Runoff estimates for small watersheds and development of sound design: Federal Highway Administration Report FHWA-RD-77-158.

Federal Highway Administration, 1993, Stream Stability and Scour at Highway Bridges: Participant Workbook: Federal Highway Administration Report FHWA-HI-91-011.

Federal Emergency Management Agency, 1989, Flood Insurance Study, Town of Royalton, Windsor County, Vermont: Washington, D.C., June 5, 1989

Froehlich, D.C., 1989, Local scour at bridge abutments in Ports, M.A., ed., Hydraulic Engineering--Proceedings of the 1989 National Conference on Hydraulic Engineering: New York, American Society of Civil Engineers, p. 13-18.

Hayes, D.C.,1993, Site selection and collection of bridge-scour data in Delaware, Maryland, and Virginia: U.S. Geological Survey WaterResources Investigation Report 93-4017, 23 p.

Interagency Advisory Committee on Water Data, 1982, Guidelines for determining flood flow frequency: U.S. Geological Survey, Bulletin 17B of the Hydrology Subcommittee, 190 p.

Johnson, C.G. and Tasker, G.D.,1974, Progress report on flood magnitude and frequency of Vermont streams: U.S. Geological Survey OpenFile Report 74-130, 37 p.

Lagasse, P.F., Schall, J.D., Johnson, F., Richardson, E.V., Chang, F., 1995, Stream Stability at Highway Structures: Federal Highway Administration Hydraulic Engineering Circular No. 20, Publication FHWA-IP-90-014, 144 p.

Laursen, E.M., 1960, Scour at bridge crossings: Journal of the Hydraulics Division, American Society of Civil Engineers, v. 86, no. HY2, p. 39-53.

Potter, W. D., 1957a, Peak rates of runoff in the Adirondack, White Mountains, and Maine woods area, Bureau of Public Roads

Potter, W. D., 1957b, Peak rates of runoff in the New England Hill and Lowland area, Bureau of Public Roads

Richardson, E.V. and Davis, S.R., 1995, Evaluating scour at bridges: Federal Highway Administration Hydraulic Engineering Circular No. 18, Publication FHWA-IP-90-017, 204 p.

Richardson, E.V., Simons, D.B., and Julien, P.Y., 1990, Highways in the river environment: Federal Highway Administration Publication FHWA-HI-90-016.

Ritter, D.F., 1984, Process Geomorphology: W.C. Brown Co., Debuque, Iowa, 603 p.

Shearman, J.O., 1990, User's manual for WSPRO--a computer model for water surface profile computations: Federal Highway Administration Publication FHWA-IP-89-027, 187 p.

Shearman, J.O., Kirby, W.H., Schneider, V.R., and Flippo, H.N., 1986, Bridge waterways analysis model; research report: Federal Highway Administration Publication FHWA-RD-86-108, 112 p.

Talbot, A.N., 1887, The determination of water-way for bridges and culverts.

U.S. Department of Transportation, 1993, Stream stability and scour at highway bridges, Participant Workbook: Federal Highway Administration Publication FHWA HI-91-011.

U.S. Geological Survey, 1981, Randolph Center, Vermont 7.5 Minute Series quadrangle map: U.S. Geological Survey Topographic Maps, Photoinspected 1983, Scale 1:24,000. 


\section{APPENDIX A: \\ WSPRO INPUT FILE}




\section{WSPRO INPUT FILE}

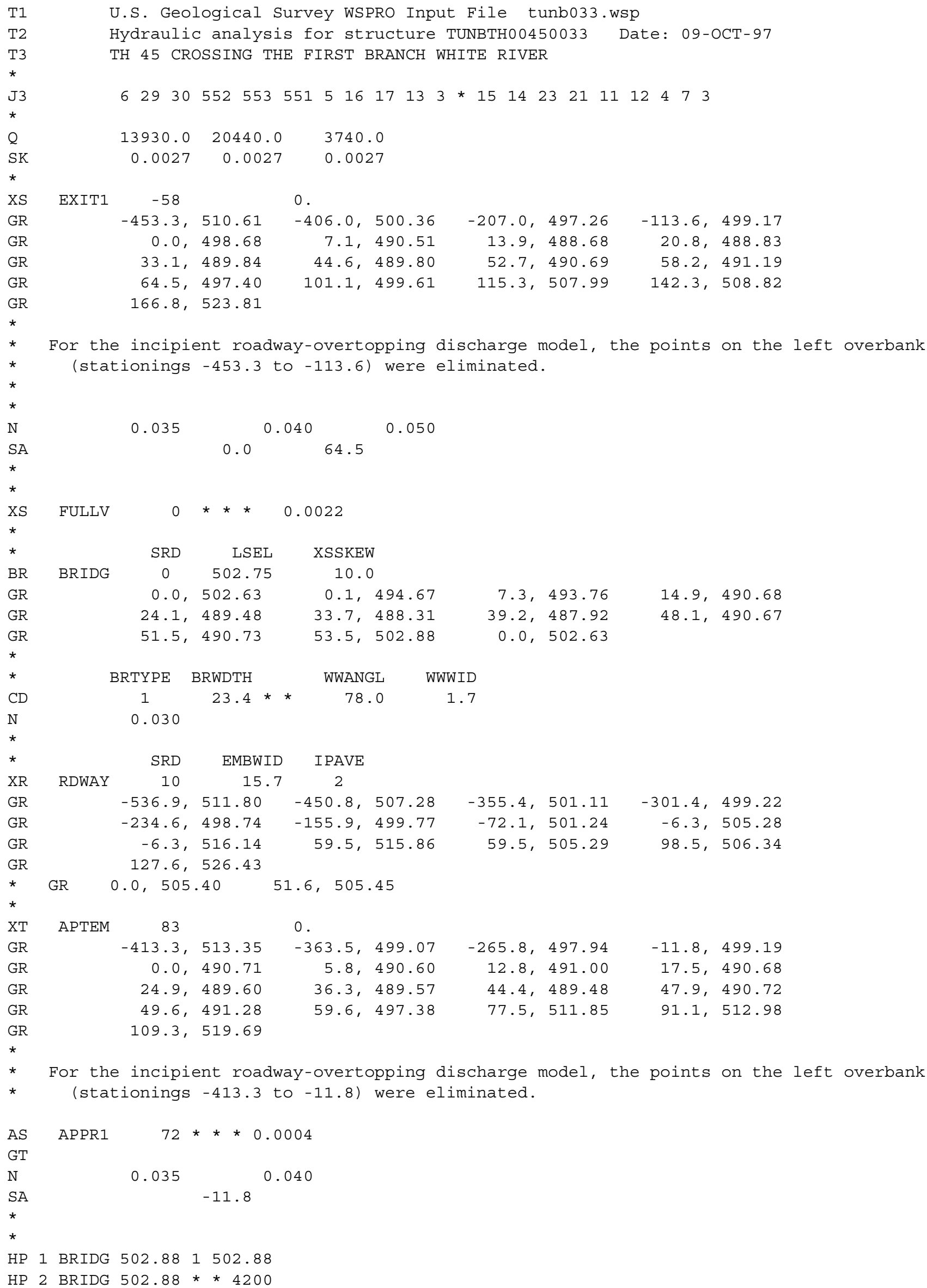


WSPRO INPUT FILE (continued)

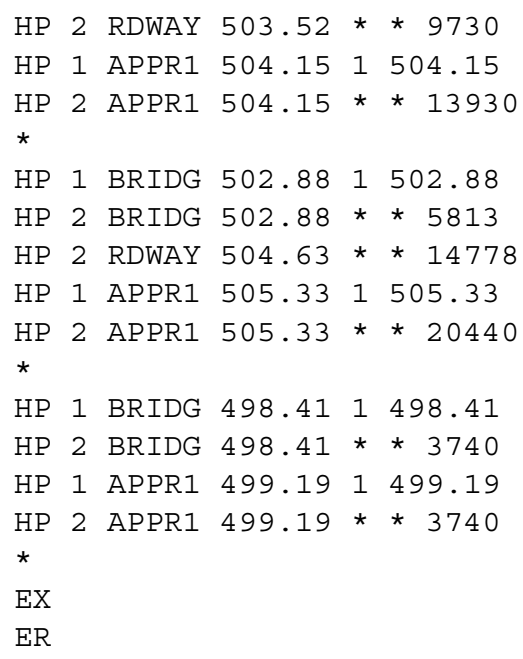




\section{APPENDIX B: \\ WSPRO OUTPUT FILE}


WSPRO OUTPUT FILE

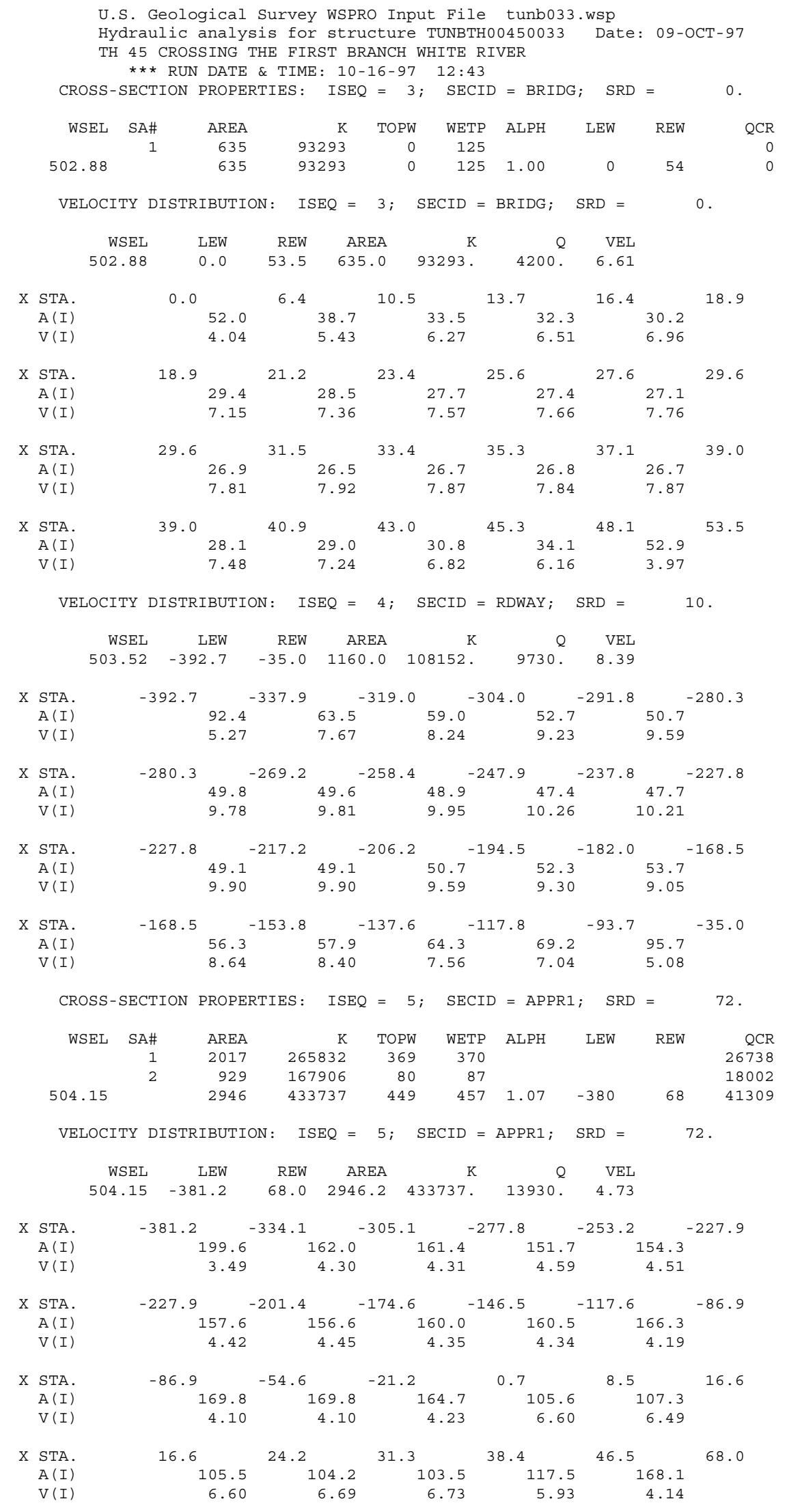


WSPRO OUTPUT FILE (continued)

\author{
U.S. Geological Survey WSPRO Input File tunb033.wsp \\ Hydraulic analysis for structure TUNBTH00450033 Date: 09-OCT-97 \\ TH 45 CROSSING THE FIRST BRANCH WHITE RIVER \\ *** RUN DATE \& TIME: 10-16-97 12:43 \\ CROSS-SECTION PROPERTIES: ISEQ $=3 ;$ SECID $=$ BRIDG; $\quad$ SRD $=0$. \\ $\begin{array}{rrrrrrrrrr}\text { WSEL } & \text { SA\# } & \text { AREA } & \text { K } & \text { TOPW } & \text { WETP } & \text { ALPH } & \text { LEW } & \text { REW } & \text { QCR } \\ & 1 & 635 & 93293 & 0 & 125 & & & & 0 \\ 02.88 & & 635 & 93293 & 0 & 125 & 1.00 & 0 & 54 & 0\end{array}$ \\ VELOCITY DISTRIBUTION: ISEQ = 3; SECID = BRIDG; $\quad$ SRD $=0$.

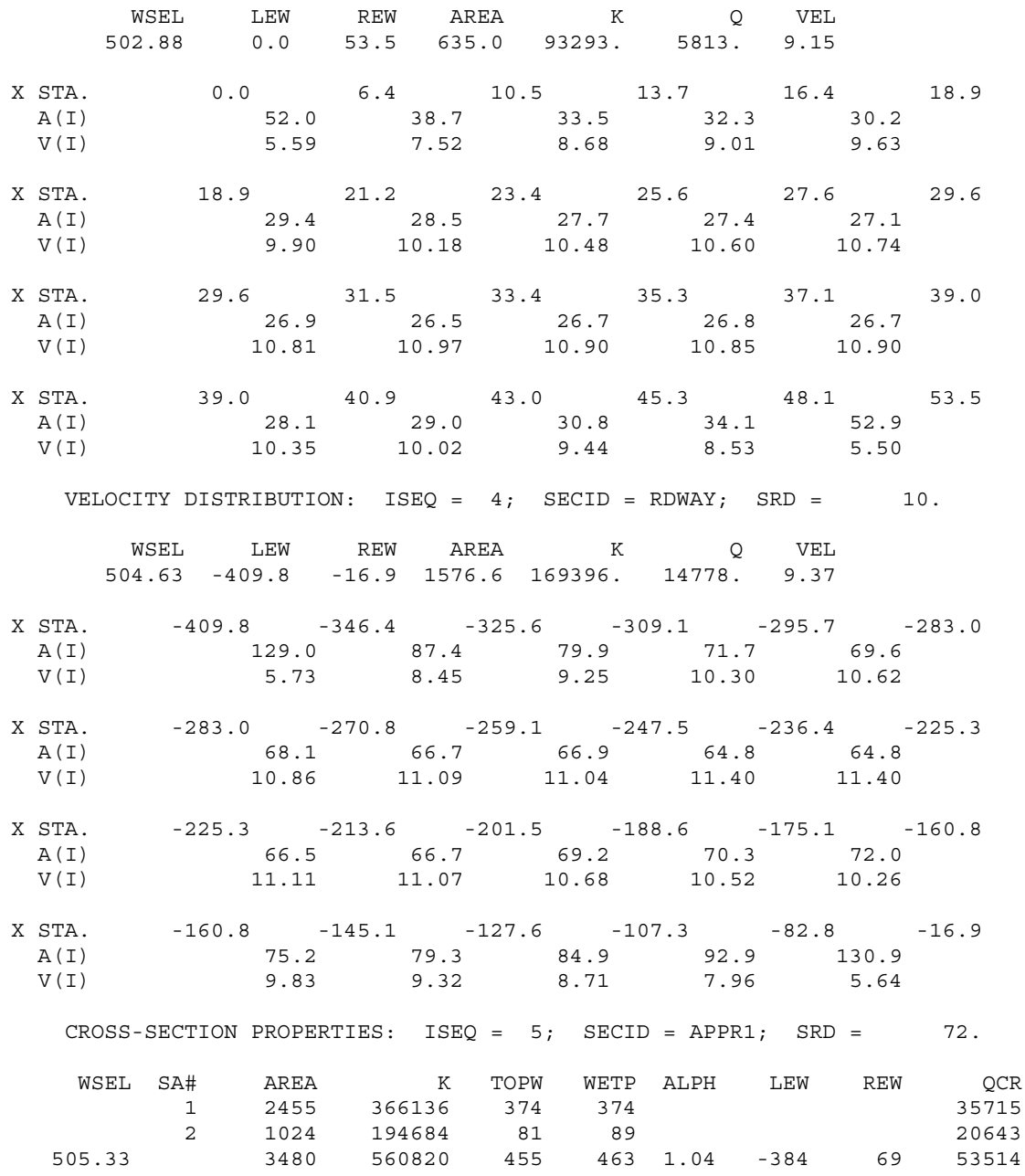 \\ VELOCITY DISTRIBUTION: ISEQ $=5 ;$ SECID $=$ APPR1; $\quad$ SRD $=72$.

$\begin{array}{rrrrrrr}\text { WSEL } & \text { LEW } & \text { REW } & \text { AREA } & \text { K } & Q & \text { VEL } \\ 505.33 & -385.3 & 69.4 & 3479.5 & 560820 . & 20440 . & 5.87\end{array}$

\begin{tabular}{|c|c|c|c|c|c|c|c|}
\hline \multirow[t]{3}{*}{$\mathrm{X}$} & STA. & -385.3 & -338.1 & -309.7 & -283.9 & -259.3 & -235.0 \\
\hline & $A(I)$ & 231.6 & 190.7 & 181.1 & 180.1 & & \\
\hline & $V(I)$ & 4.41 & 5.36 & 5.64 & 5.67 & & \\
\hline \multirow[t]{3}{*}{$\mathrm{X}$} & STA. & -235.0 & -210.4 & -184.6 & -158.7 & -131.7 & -103.8 \\
\hline & $A(I)$ & 176.7 & 182.3 & 179.4 & 183.8 & & \\
\hline & $\mathrm{V}(\mathrm{I})$ & 5.78 & 5.61 & 5.70 & 5.56 & & \\
\hline \multirow[t]{3}{*}{$\mathrm{X}$} & STA. & -103.8 & -75.2 & -44.8 & -13.9 & 2.7 & 11.7 \\
\hline & $A(I)$ & 186.4 & 194.0 & 192.4 & 175.3 & & \\
\hline & $V(I)$ & 5.48 & 5.27 & 5.31 & 5.83 & & \\
\hline \multirow[t]{3}{*}{$\mathrm{X}$} & STA. & 11.7 & 20.5 & 28.7 & 37.0 & 45.8 & 69.4 \\
\hline & $A(I)$ & 127.6 & 128.9 & 130.0 & 138.3 & & \\
\hline & $V(I)$ & 8.01 & 7.93 & 7.86 & 7.39 & & \\
\hline
\end{tabular}


WSPRO OUTPUT FILE (continued)

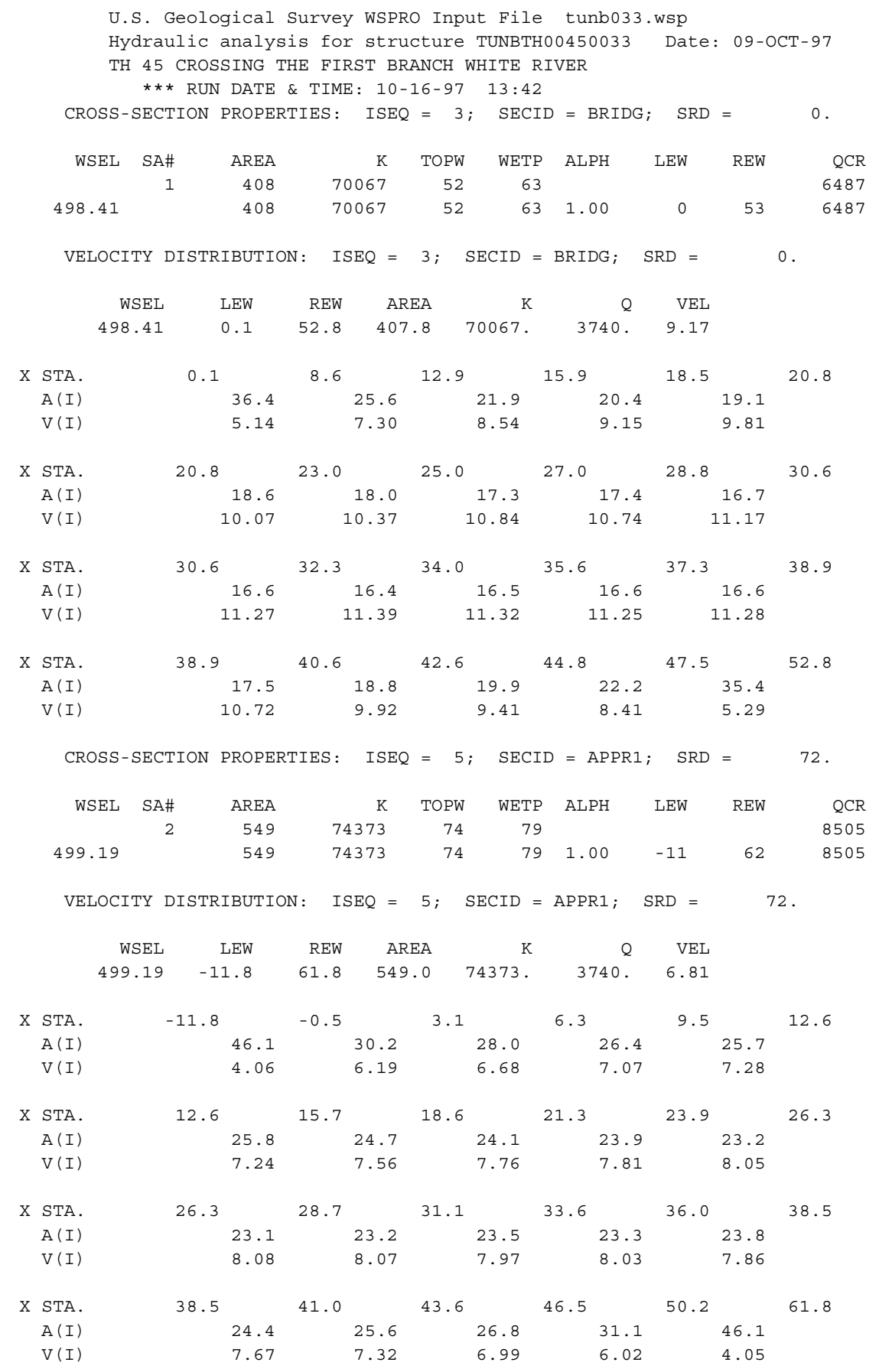




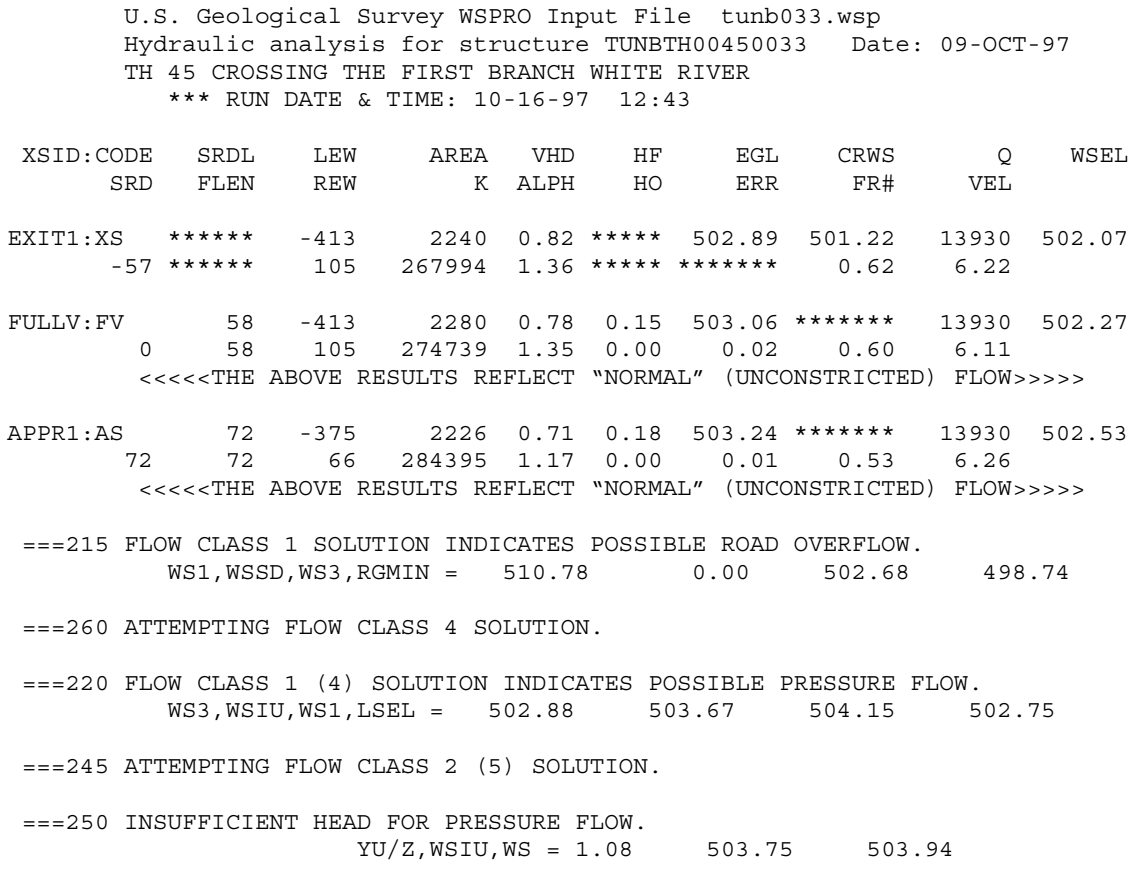


WSPRO OUTPUT FILE (continued)

$\begin{array}{cccr}\text { XSID : CODE } & \text { XLKQ } & \text { XRKQ } & \text { KQ } \\ \text { APPRI : AS } & -66 . & -12 . & 34377 .\end{array}$

SECOND USER DEFINED TABLE.

$\begin{array}{lcrrrrrrrr}\text { XSID : CODE } & \text { CRWS } & \text { FR\# } & \text { YMIN } & \text { YMAX } & \text { HF } & \text { HO } & \text { VHD } & \text { EGL } & \text { WSEL } \\ \text { EXIT1:XS } & 501.22 & 0.62 & 488.68 & 523.81 * * * * * * * * * * * & 0.82 & 502.89 & 502.07 \\ \text { FULLV:FV } & * * * * * * * * & 0.60 & 488.81 & 523.94 & 0.15 & 0.00 & 0.78 & 503.06 & 502.27 \\ \text { BRIDG:BR } & 496.42 & 0.43 & 487.92 & 502.88 & 0.52 & 0.75 & 1.12 & 504.00 & 502.88 \\ \text { RDWAY:RG } & * * * * * * * * * * * * * * * * & 498.74 & 526.43 & 0.06 * * * * * * & 0.37 & 504.47 & 503.52 \\ \text { APPRI:AS } & 501.18 & 0.34 & 489.48 & 519.69 & 0.47 & 0.05 & 0.37 & 504.52 & 504.15\end{array}$

U.S. Geological Survey WSPRO Input File tunb033.wsp

Hydraulic analysis for structure TUNBTH00450033 Date: 09-OCT-97

TH 45 CROSSING THE FIRST BRANCH WHITE RIVER

*** RUN DATE \& TIME: 10-16-97 12:43

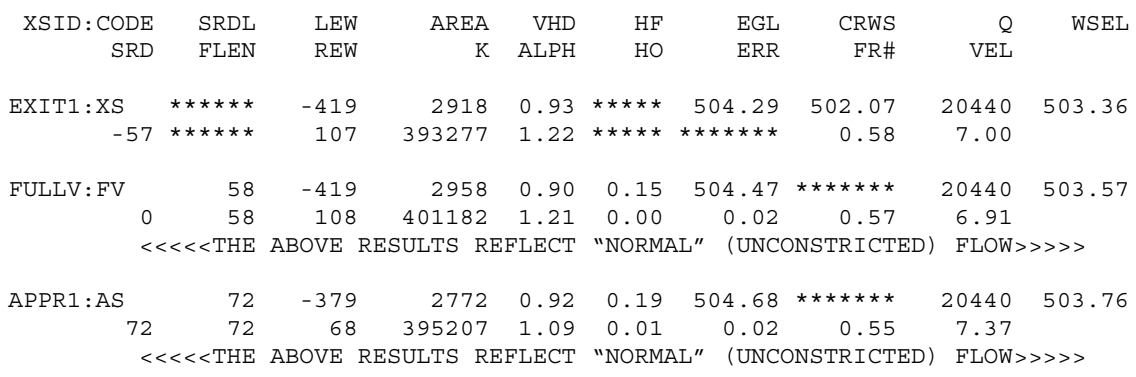

$==255$ ATTEMPTING FLOW CLASS 3 (6) SOLUTION.

WS3N, LSEL $=503.57 \quad 502.75$

<<<<RESULTS REFLECTING THE CONSTRICTED FLOW FOLLOW >>>>>

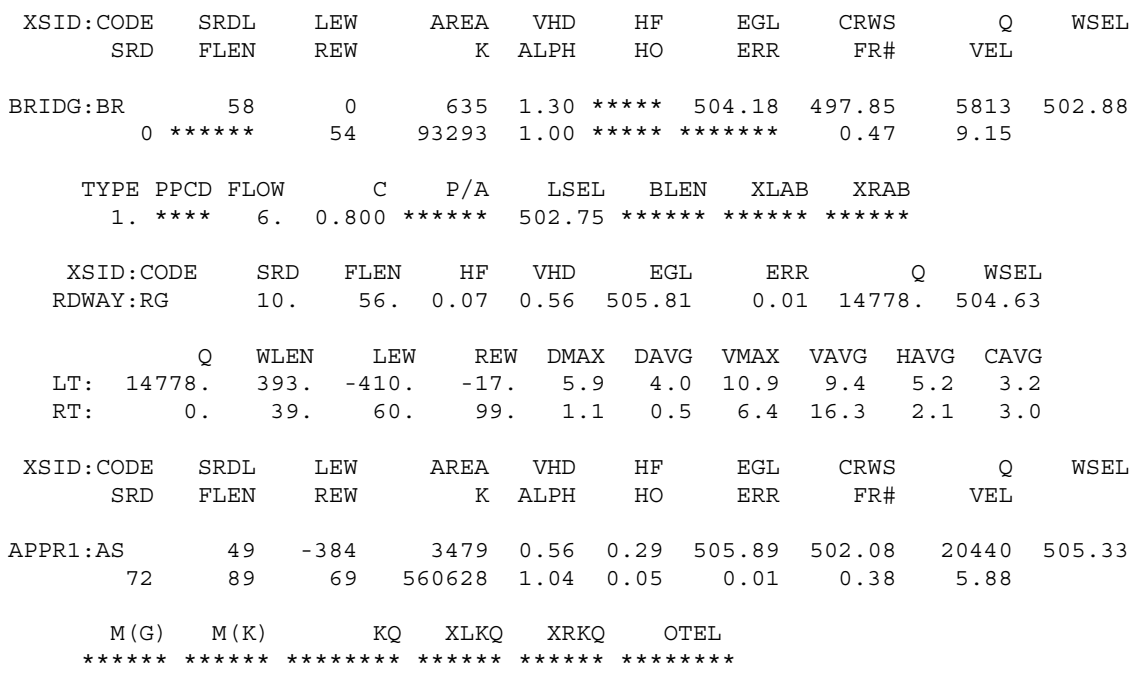

$<<<<$ END OF BRIDGE COMPUTATIONS $>>>>>$

FIRST USER DEFINED TABLE.

\begin{tabular}{|c|c|c|c|c|c|c|c|c|}
\hline XSID : CODE & SRD & LEW & REW & $\mathrm{Q}$ & $\mathrm{K}$ & AREA & VEL & WSEL \\
\hline EXIT1:XS & -58 & -420 . & 107. & 20440 . & 393277 . & 2918 . & 7.00 & 503.36 \\
\hline FULLV : FV & 0 & -420 . & 108. & 20440 . & 401182 . & 2958 . & 6.91 & 503.57 \\
\hline BRIDG : BR & 0 & 0 & 54 & 5813 & 93293. & 635 & 9.15 & 502.88 \\
\hline RDWAY : RG & $10 . *$ & $* \star \star \star \star * \star$ & 14778 . & 14778 * & $\star * * * * * * *$ & 0 & 2.00 & 504.63 \\
\hline APPR1: AS & 72. & -385 & 69 & 20440 & 560628 & 3479 . & 5.88 & 505.33 \\
\hline XSID : CODE & XLKQ & XRKQ & & & & & & \\
\hline
\end{tabular}

SECOND USER DEFINED TABLE.

$\begin{array}{lcrrrrrrrr}\text { XSID : CODE } & \text { CRWS } & \text { FR\# } & \text { YMIN } & \text { YMAX } & \text { HF } & \text { HO } & \text { VHD } & \text { EGL } & \text { WSEL } \\ \text { EXIT1:XS } & 502.07 & 0.58 & 488.68 & 523.81 * * * * * * * * * * & 0.93 & 504.29 & 503.36 \\ \text { FULLV:FV } & * * * * * * * * & 0.57 & 488.81 & 523.94 & 0.15 & 0.00 & 0.90 & 504.47 & 503.57 \\ \text { BRIDG : BR } & 497.85 & 0.47 & 487.92 & 502.88 * * * * * * * * * * & 1.30 & 504.18 & 502.88 \\ \text { RDWAY:RG } & * * * * * * * * * * * * * * * * & 498.74 & 526.43 & 0.07 * * * * * * & 0.56 & 505.81 & 504.63 \\ \text { APPR1:AS } & 502.08 & 0.38 & 489.48 & 519.69 & 0.29 & 0.05 & 0.56 & 505.89 & 505.33\end{array}$




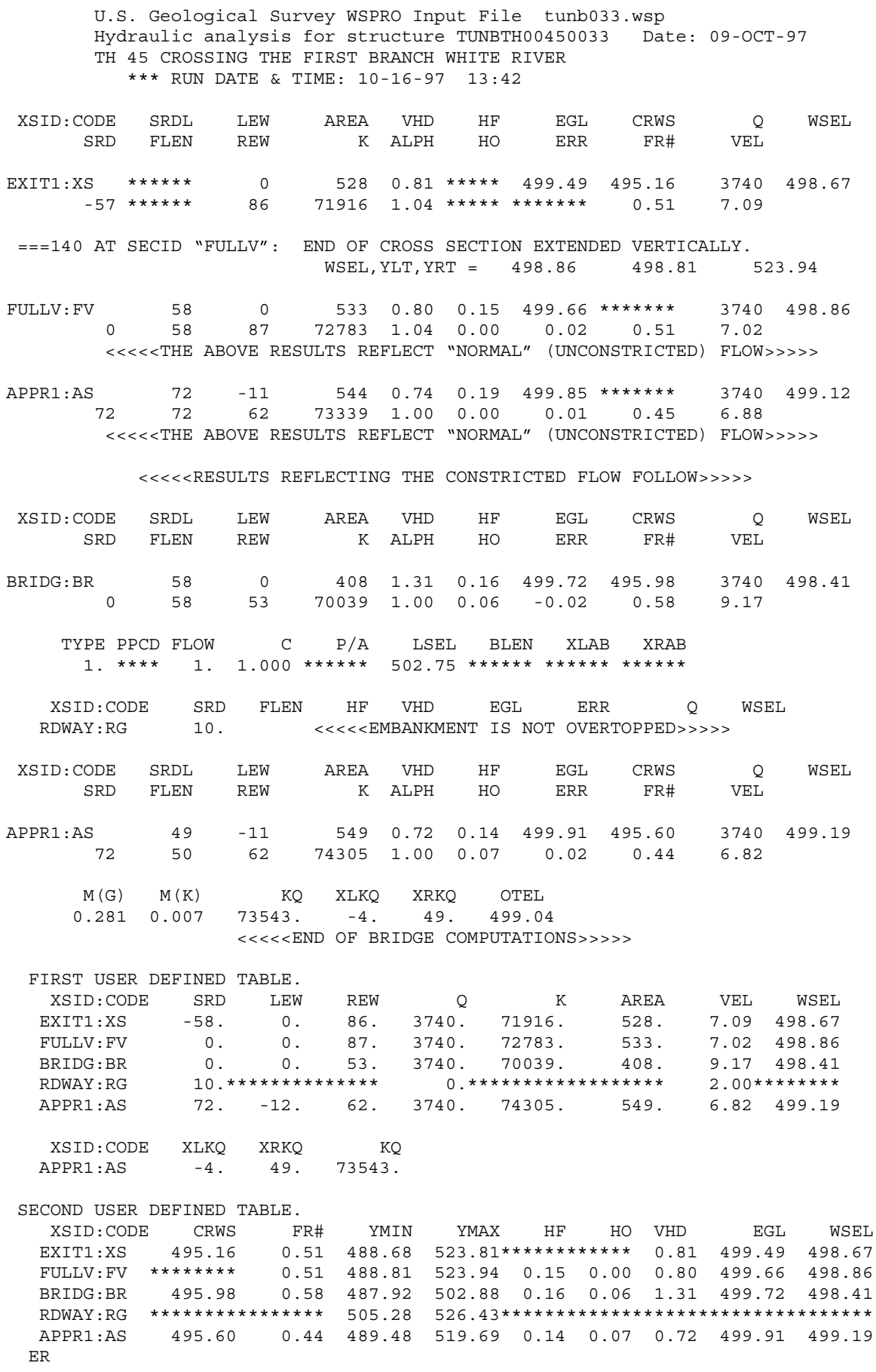




\section{APPENDIX C:}

\section{BED-MATERIAL PARTICLE-SIZE DISTRIBUTION}




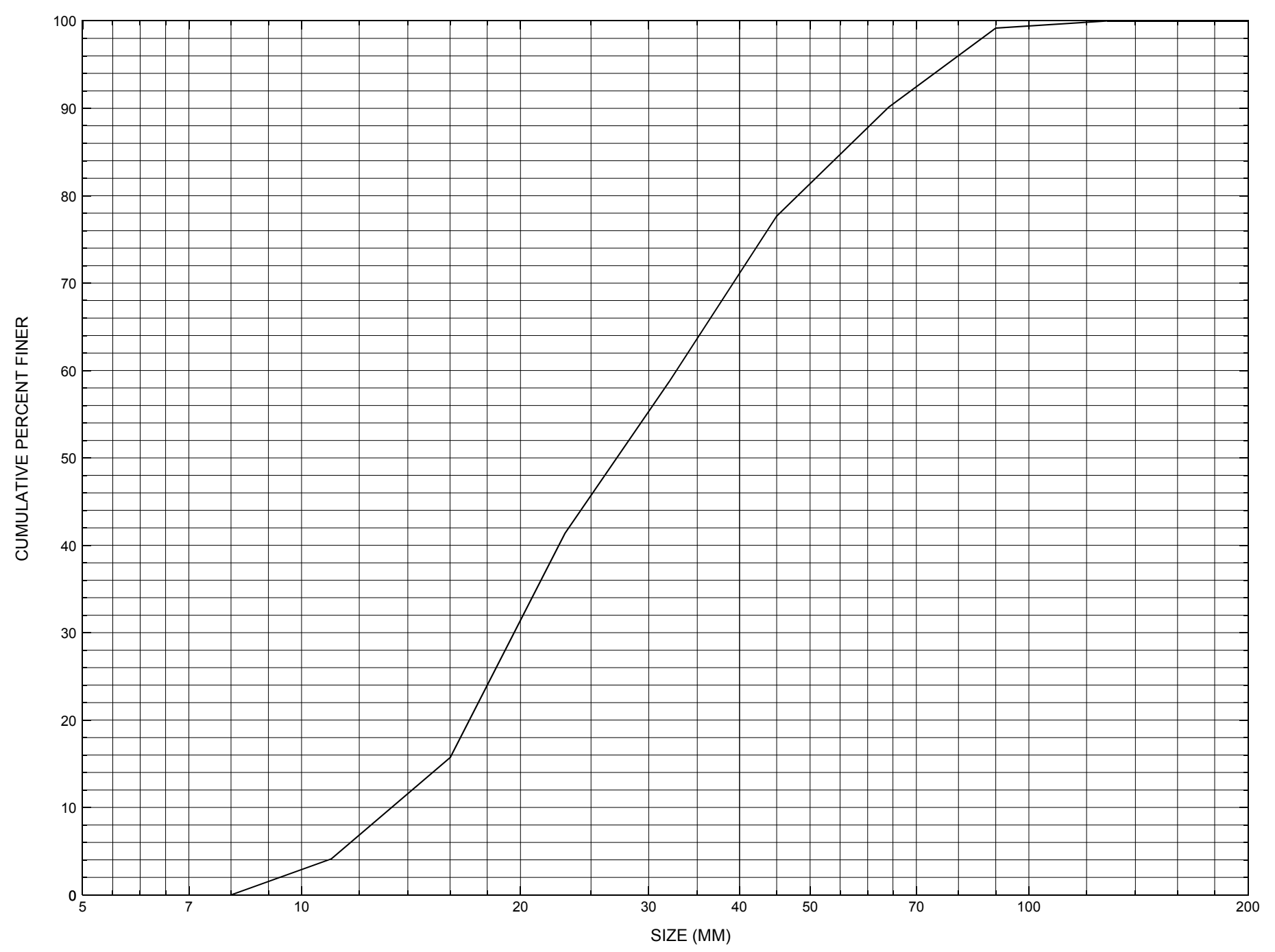

Appendix C. Bed material particle-size distribution for a pebble count in the channel approach of structure TUNBTH00450033, in Tunbridge, Vermont. 


\section{APPENDIX D: \\ HISTORICAL DATA FORM}




\section{Structure Number TUNBTH00450033}

\section{General Location Descriptive}

Data collected by (First Initial, Full last name) $\mathbf{E}$. BOEHMLER

Date $(M M / D D / Y Y) \_\mathbf{0 3} / \underline{23} / \underline{95}$

Highway District Number (I - 2; nn) 04

Town (FIPS place code; I - 4; nnnnn) $\mathbf{7 3 6 7 5}$

Waterway ( $($ - 6) FIRST BRANCH WHITE RIVER

Route Number TH045

Topographic Map Randolph.Center

Latitude (I - 16; nnnn.n) $\mathbf{4 3 5 2 9}$
County (FIPS county code; I - 3; nnn)

Mile marker (I - 11; nnn.nnn) $\mathbf{0 0 0 0 0 0}$

Road Name (I - 7): -

Vicinity (I - 9) 0.1 MI JCT TH $45+$ VT110

Hydrologic Unit Code: $\mathbf{0 1 0 8 0 1 0 5}$

Longitude (i - 17; nnnnn.n) $\mathbf{7 2 3 0 3}$

\section{Select Federal Inventory Codes}

FHWA Structure Number (I - 8) 10091300330913

Maintenance responsibility $(I-21 ; n n) \_$03 _ Maximum span length $(I-48$; $n n n n) \underline{\mathbf{0 0 5 4}}$

Year built (I - 27; YYYY) 1883

Structure length (I - 49; nnnnnn) $\underline{\mathbf{0 0 0 0 6 7}}$

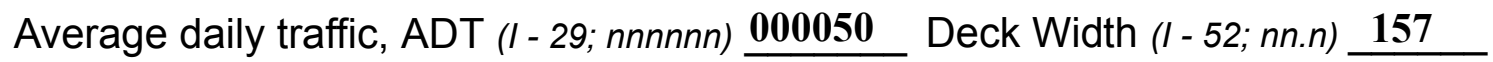

Year of ADT (I-30; YY) $\underline{\mathbf{9 1}}$

Channel \& Protection $(I-61 ; n) \underline{7}$

Opening skew to Roadway $(I-34 ; n n) \quad \mathbf{0 0}$

Waterway adequacy $(I-71 ; n)$

Operational status $(I-41 ; X) \mathbf{A}$

Underwater Inspection Frequency $(I-92 B ; X Y Y) \_\mathbf{N}$

Structure type (I - 43; nnn) $\mathbf{7 1 0}$

Year Reconstructed (I - 106) $\mathbf{0 0 0 0}$

Approach span structure type (I - 44; nnn) $\mathbf{0 0 0}$

Clear span (nnn.n ft) _ _

Number of spans (I - 45; nnn) $\mathbf{0 0 1}$

Vertical clearance from streambed (nnn.n ft) $\underline{\mathbf{0 1 3 . 0}}$

Number of approach spans (I - 46; nnnn) $\mathbf{0 0 0 0}$

Waterway of full opening $\left(n n n . n \mathrm{ft}^{2}\right)$

Comments:

The structural inspection report of 11/1/93 indicates that the structure is a timber, thru-truss, multiple king post type covered bridge. The right abutment is concrete while the left is constructed of stone. The right abutment has no problems. The left abutment is reported as having a cantilevered section of stone near the low superstructure. Otherwise, the stone work is in good condition. The report mentions that there is no evident channel scour or bank erosion. A minor sand bar is along the left abutment and the channel makes a sharp bend into the crossing. The riprap coverage is noted as fair. The streambed consists of stone and gravel with some sand. 


\section{Bridge Hydrologic Data}

Is there hydrologic data available? $\underline{\mathbf{N}}$ if No, type ctrl-n $h \quad$ VTAOT Drainage area $\left(m i^{2}\right)$ : -

Terrain character:

Stream character \& type: -

Streambed material:

Discharge Data (cfs):

$$
\begin{aligned}
& Q_{2.33}- \\
& Q_{50}-
\end{aligned}
$$

Record flood date $(M M / D D / Y Y)$ :

Estimated Discharge (cfs): Ice conditions (Heavy, Moderate, Light) : -

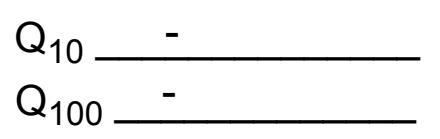

$$
\begin{aligned}
& Q_{25}- \\
& Q_{500}-
\end{aligned}
$$

Water surface elevation $(f t):-$

The stage increases to maximum highwater elevation (Rapidly, Not rapidly):

The stream response is (Flashy, Not flashy):

Describe any significant site conditions upstream or downstream that may influence the stream's stage: -

Watershed storage area (in percent): _ _ \%

The watershed storage area is: - (1-mainly at the headwaters; 2- uniformly distributed; 3-immediatly upstream oi the site)

Water Surface Elevation Estimates for Existing Structure:

\begin{tabular}{|l|l|l|l|l|l|}
\hline Peak discharge frequency & $Q_{2.33}$ & $Q_{10}$ & $Q_{25}$ & $Q_{50}$ & $Q_{100}$ \\
Water surface elevation (ft)) & - & - & - & - & - \\
Velocity (ft/sec) & - & - & - & - & - \\
\hline
\end{tabular}

Long term stream bed changes: -

Is the roadway overtopped below the $\mathrm{Q}_{100}$ ? (Yes, No, Unknown): $\mathbf{U} \quad$ Frequency: Relief Elevation (ft): Discharge over roadway at $Q_{100}\left(f^{3} / \mathrm{sec}\right)$ :

Are there other structures nearby? (Yes, No, Unknown): $\underline{\mathbf{U}}$ Upstream distance (miles): Town: If No or Unknown, type ctrl-n os Highway No. : Structure No. : Year Built:

Clear span (ft): Clear Height $(f t)$ : Full Waterway $\left(f^{2}\right)$ : 
Downstream distance (miles): Town: Year Built:

Highway No. : Structure No. : Structure Type:

Clear span $(f t):$ Clear Height $(f t)$ : Full Waterway $\left(f^{2}\right)$ : -

Comments:

\section{USGS Watershed Data}

Watershed Hydrographic Data

Drainage area $(D A) \stackrel{86.39}{\mathrm{mi}^{2}}$

Watershed storage (ST) 0.1

Bridge site elevation 520

Main channel length 17.83 $\mathrm{ft}$ $\%$ $10 \%$ channel length elevation $\quad \mathbf{5 6 0}$ $\mathrm{ft} \quad 85 \%$ channel length elevation $\mathrm{ft}$

Main channel slope $(S)$

(S) 53.09 $\mathrm{ft} / \mathrm{mi}$

Watershed Precipitation Data

Average site precipitation in Average headwater precipitation in

Maximum 2yr-24hr precipitation event $(124,2)$ in

Average seasonal snowfall (Sn) $\mathrm{ft}$ 


\section{Bridge Plan Data}

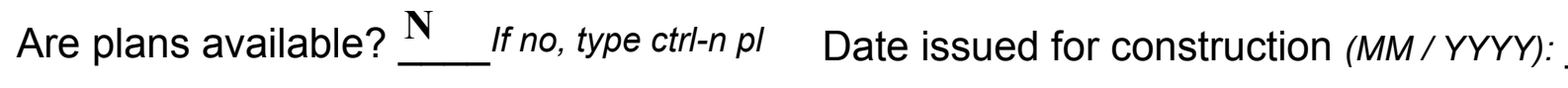

Project Number

Minimum channel bed elevation:

Low superstructure elevation: USLAB DSLAB USRAB DSRAB Benchmark location description:

NO BENCHMARK INFORMATION

Reference Point (MSL, Arbitrary, Other): Datum (NAD27, NAD83, Other):

Foundation Type: 4

If 1 : Footing Thickness

If 2: Pile Type:

If 3: Footing bottom elevation:

Is boring information available? $\mathbf{N}$

Foundation Material Type: $\mathbf{3}$

(1-Spreadfooting; 2-Pile; 3- Gravity; 4-Unknown)

Footing bottom elevation: -

Briefly describe material at foundation bottom elevation or around piles:

NO FOUNDATION MATERIAL INFORMATION

Comments:

NO PLANS. 


\section{Cross-sectional Data}

Is cross-sectional data available? Yes If no, type ctrl-n xs

Source (FEMA, VTAOT, Other)? VTAOT

The station and low chord to bed differences are from a sketch dated 11/1/93 that is attached Comments: to a bridge inspection report. The low chord elevations are from the 10/18/95 survey done for this report. This section is of the upstream face.

\begin{tabular}{|c|c|c|c|c|c|c|c|c|c|c|c|}
\hline Station & 0 & 15 & 27 & 39 & 54 & - & - & - & - & - & - \\
\hline Feature & LAB & - & - & - & RAB & - & - & - & - & - & - \\
\hline $\begin{array}{l}\text { Low chord } \\
\text { elevation }\end{array}$ & 502.60 & 502.68 & 502.74 & 502.80 & 502.88 & - & - & - & - & - & - \\
\hline $\begin{array}{l}\text { Bed } \\
\text { elevation }\end{array}$ & 494.30 & 490.18 & 488.24 & 486.80 & 489.38 & - & - & - & - & - & - \\
\hline $\begin{array}{l}\text { Low chord } \\
\text { to bed }\end{array}$ & 8.3 & 12.5 & 14.5 & 16 & 13.5 & - & - & - & - & - & - \\
\hline Station & - & - & - & - & - & - & - & - & - & - & - \\
\hline Feature & - & - & - & - & - & - & - & - & - & - & - \\
\hline $\begin{array}{l}\text { Low chord } \\
\text { elevation }\end{array}$ & - & - & - & - & - & - & - & - & - & - & - \\
\hline $\begin{array}{l}\text { Bed } \\
\text { elevation }\end{array}$ & - & - & - & - & - & - & - & - & - & - & - \\
\hline $\begin{array}{l}\text { Low chord } \\
\text { to bed }\end{array}$ & - & - & - & - & - & - & - & - & - & - & - \\
\hline
\end{tabular}

Source (FEMA, VTAOT, Other)?

Comments: -

\begin{tabular}{|l|l|l|l|l|l|l|l|l|l|l|l|l|}
\hline Station & - & - & - & - & - & - & - & - & - & - \\
\hline Feature & - & - & - & - & - & - & - & - & - & - \\
\hline $\begin{array}{l}\text { Low chord } \\
\text { elevation }\end{array}$ & - & - & - & - & - & - & - & - & - & - & - \\
\hline $\begin{array}{l}\text { Bed } \\
\text { elevation }\end{array}$ & - & - & - & - & - & - & - & - & - & - \\
\hline $\begin{array}{l}\text { Low chord } \\
\text { to bed }\end{array}$ & - & - & - & - & - & - & - & - & - & - & - \\
\hline \begin{tabular}{l} 
Station \\
\hline \begin{tabular}{l} 
Feature \\
\hline
\end{tabular}
\end{tabular}$-$ & - & - & - & - & - & - & - & - & - & - \\
\hline $\begin{array}{l}\text { Low chord } \\
\text { elevation }\end{array}$ & - & - & - & - & - & - & - & - & - & - \\
\hline $\begin{array}{l}\text { Bed } \\
\text { elevation }\end{array}$ & - & - & - & - & - & - & - & - & - & - \\
\hline $\begin{array}{l}\text { Low chord } \\
\text { to bed }\end{array}$ & - & - & - & - & - & - & - & - & - & - \\
\hline
\end{tabular}




\section{APPENDIX E: \\ LEVEL I DATA FORM}


U. S. Geological Survey

Bridge Field Data Collection and Processing Form

Qa/Qc Check by: $\mathbf{R B}$ Date: $4 / 10 / 96$

Computerized by: $\mathbf{R B}$ Date: $4 / 10 / 96$

\section{Structure Number TUNBTH00450033}

Reviewd by: EW Date: 10/24/97

\section{A. General Location Descriptive}

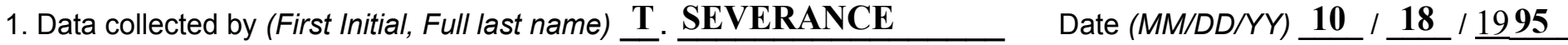

2. Highway District Number $\mathbf{0 4}$

County ORANGE 017

Waterway (l - 6) FIRST BRANCH WHITE RIVER

Route Number $\mathbf{T H 4 5}$

3. Descriptive comments:

Located 0.1 mile to the junction with VT 110. This is a wooden covered bridge located at the edge of the valley floor. Markings on the bridge above the left bank entrance state, "Cilley Bridge 1883."
Mile marker $\mathbf{0 0 0}$

Town TUNBRIDGE 73675

Road Name -

Hydrologic Unit Code: $\mathbf{0 1 0 8 0 1 0 5}$

\section{B. Bridge Deck Observations}

\section{Surface cover... $\quad$ LBUS $4 \quad$ RBUS $4 \quad$ LBDS $4 \quad$ RBDS 4 Overall 4}

(2b us,ds,lb,rb: 1- Urban; 2- Suburban; 3- Row crops; 4- Pasture; 5- Shrub- and brushland; 6- Forest; 7- Wetland)

5. Ambient water surface...US $\underline{1}$ UB $\underline{1}$ DS $\underline{1}$ (1-pool; 2- riffle)

6. Bridge structure type 1 (1- single span; 2- multiple span; 3- single arch; 4- multiple arch; 5-cylindrical culvert; 6- box culvert; or 7- other)
7. Bridge length 67
(feet)
Span length $\underline{\mathbf{5 4}}$
(feet)
Bridge width 15.7 (feet)

\section{Road approach to bridge:}
8. LB 1
RB 2
( 0 even, 1- lower, 2- higher)
9. LB_ RB 1
(1-Paved, 2- Not paved)

10. Embankment slope (run / rise in feet / foot)

US left

US right

\begin{tabular}{|c|c|c|c|}
\hline \multicolumn{2}{|c|}{ Protection } & \multirow{2}{*}{ 13.Erosion } & 14.Severity \\
\hline 11.Type & 12.Cond. & $\mathbf{0}$ & - \\
\hline $\mathbf{0}$ & - & $\mathbf{0}$ & - \\
$\mathbf{0}$ & - & $\mathbf{0}$ & - \\
\hline $\mathbf{0}$ & - & $\mathbf{2}$ & $\mathbf{2}$ \\
\hline $\mathbf{0}$ & - & $\mathbf{0}$ & - \\
\hline
\end{tabular}

Bank protection types: 0- none; 1- < 12 inches;

2- < 36 inches; 3- < 48 inches;

4- < 60 inches; 5- wall / artificial levee

Bank protection conditions: 1- good; 2- slumped;

3- eroded; 4- failed

Erosion: 0 - none; 1- channel erosion; 2 -

road wash; 3- both; 4- other

Erosion Severity: 0 - none; 1- slight; 2- moderate;

\section{Channel approach to bridge (BF):}

15. Angle of approach: $\mathbf{1 0}$

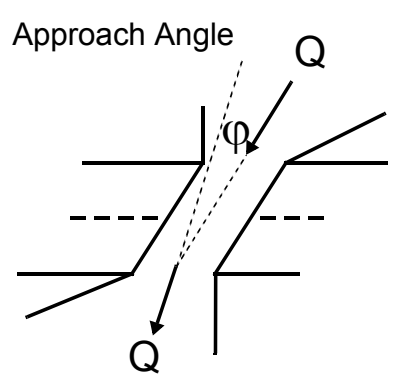

17. Channel impact zone 1 :

Where? RB (LB, RB)

Range? 0 feet DS

Channel impact zone 2:

Where? - $(L B, R B)$

Range? - $\quad$ feet -

(US, UB, DS) to Impact Severity: 0- none to very slight; 1- Slight; 2- Moderate; 3- Severe feet -

16. Bridge skew: 20 Bridge Skew Angle

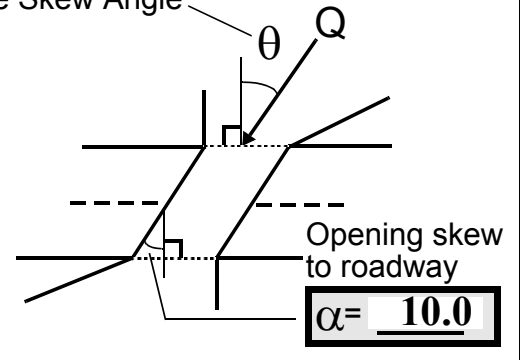

\section{Exist? $\mathbf{Y}(\mathrm{Y}$ or $N)$}

Severity 1

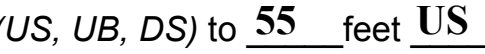

Exist? $\mathbf{N}(Y$ or $N)$

Severity - 
18. Bridge Type: $\underline{\mathbf{1 a} / \mathbf{1 b}}$

1a- Vertical abutments with wingwalls

1 b- Vertical abutments without wingwalls

2- Vertical abutments and wingwalls, sloping embankment Wingwalls parallel to abut. face

3- Spill through abutments

4- Sloping embankment, vertical wingwalls and abutments

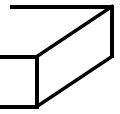

Wingwall angle less than $90^{\circ}$.
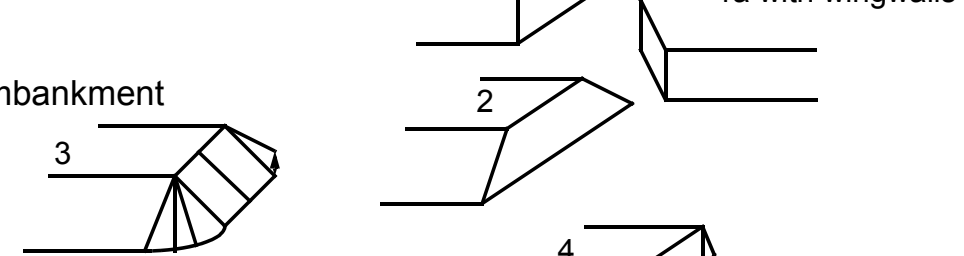

19. Bridge Deck Comments (surface cover variations, measured bridge and span lengths, bridge type variations, approach overflow width, etc.)

7. Values are from the VT AOT files. Measured bridge length is 66 feet, span length is 56 feet and the bridge width is 15.7 feet.

9. The right road approach is paved for approximately 55 feet then it is unpaved beyond.

4. The US right bank climbs immediately within one bridge length up the valley wall where there are larger older trees. The left bank US is pasture and a corn field which slopes down slightly from the top of the left bank US where there are some small saplings. The DS right bank has thick brush within one bridge length , but the overbank is pasture. The left bank DS has thick brush and saplings

along the bank but the overbank is pasture. On the left bank DS and the DS side of the left road approach there are bundled white plastic wrapped hay bails.

18. The left abutment is laid up stone and is type $1 \mathrm{~b}$. The right abutment is concrete and is type $1 \mathrm{a}$.

\section{Upstream Channel Assessment}

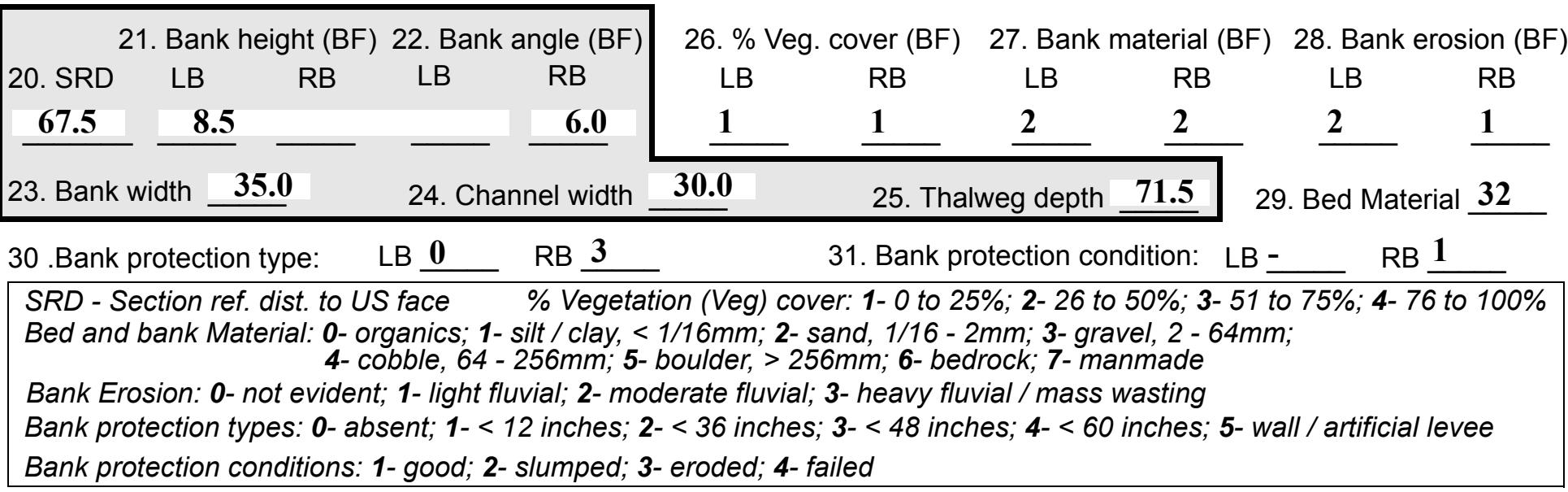

32. Comments (bank material variation, minor inflows, protection extent, etc.):

30. The US right bank stone fill dumped along the bank starts at the right abutment and extends 53 feet US. There is dumped stone fill protection, type 2, along the left bank starting at 290 feet US and continuing US several hundred feet. Between this point and the bridge there are scattered pieces of similar stone along the base of the cut bank.

28. Most of the flow is along the right bank and there is light erosion and scour is evident. Along the left bank there is a point bar and a cut bank above it. 
33.Point/Side bar present? Y

$(Y$ or N. if $N$ type ctrl-n pb) 34 . Mid-bar distance: 218

35. Mid-bar width: $\mathbf{3 3}$

36. Point bar extent: 17 feet US

(US, UB) to 260 feet $\underline{\mathbf{U S}}$

(US, UB, DS) positioned $\underline{\mathbf{0}}$

$\%$ LB to $\mathbf{7 0}$ $\%$ RB

37. Material: 32

38. Point or side bar comments (Circle Point or Side; Note additional bars, material variation, status, etc.):

The US end is primarily gravel and the DS end is mostly fines.

39. Is a cut-bank present? $\mathbf{Y}$ (Y or if $N$ type $c t r l-n c b)$

41. Mid-bank distance: 156

43. Bank damage: 1

42. Cut bank extent: $\mathbf{3 0}$
40. Where? $\mathbf{R B} \quad(L B$ or $R B)$ feet $\underline{\mathbf{U S}}$ (US, UB) to $\underline{\mathbf{2 5 0}}$ feet $\underline{\mathbf{U S}}$ (US, UB, DS)

44. Cut bank comments (eg. additional cut banks, protection condition, etc.):

The left bank above the point bar is very steep. Another cut bank is located along the right bank: mid bank distance is 195 feet, cut bank extent is 85 feet US to 300 feet US, bank damage is 3 . This is out of the 2 bridge length range.

45. Is channel scour present? $\mathbf{Y}$ ( $Y$ or if $N$ type ctrl-n cs) 46. Mid-scour distance: 10

47. Scour dimensions: Length $\underline{\mathbf{8 0}}$ Width $\underline{8}$ Depth : $\underline{\mathbf{1 . 5}}$ Position $\underline{\mathbf{6 0}} \%$ LB to $\underline{\mathbf{8 5}} \%$ RB

48. Scour comments (eg. additional scour areas, local scouring process, etc.):

15 feet DS of the bridge face the width is 8 feet, under the bridge and US it is closer to 6 feet.

49. Are there major confluences? $\mathbf{Y}$ ( $Y$ or if $N$ type ctrl- $n m c)$

51. Confluence 1: Distance $\underline{\mathbf{1 7 2}}$

Confluence 2: Distance -
52. Enters on $\underline{\mathbf{R B}}$ (LB or RB)

Enters on (LB or $R B)$

54. Confluence comments (eg. confluence name):

50. How many? 1

53. Type 2 (1- perennial; 2-ephemeral)

Type (1-perennial; 2- ephemeral)

This is a small brook currently with very little flow and much debris in the channel.

\section{Under Bridge Channel Assessment}

55. Channel restraint (BF)? LB 2

\begin{tabular}{|ccccc}
\hline \multicolumn{2}{|c}{56. Height (BF) } & \multicolumn{3}{c}{57 Angle (BF) } \\
LB & RB & LB & RB \\
$\mathbf{4 9 . 5}$ & & & $\mathbf{1 . 0}$ & \\
\hline
\end{tabular}

58. Bank width (BF) -

59. Channel width (1- natural bank; 2- abutment; 3- artificial levee)

Bed and bank Material: 0- organics; 1- silt / clay, < 1/16mm; 2- sand, 1/16 - 2mm; 3- gravel, 2 - 64mm; 4- cobble, 64 - 256mm; 5- boulder, > 256mm; 6- bedrock; 7- manmade

Bank Erosion: 0- not evident; 1- light fluvial; 2- moderate fluvial; 3- heavy fluvial / mass wasting

64. Comments (bank material variation, minor inflows, protection extent, etc.):

123

Along the left bank are fines and gravel along the right bank. The transition between the two is abrupt at $60 \%$ LB. 
65. Debris and Ice Is there debris accumulation?

(Yor $N)$ 66. Where? $\underline{Y}$

(1- Upstream; 2- At bridge; 3- Both)

67. Debris Potential 1 (1-Low; 2-Moderate; 3- High)

68. Capture Efficiency 1

(1-Low; 2- Moderate; 3- High)

69. Is there evidence of ice build-up? 1 (Y or N)

Ice Blockage Potential $\mathbf{N}$

(1- Low; 2- Moderate; 3- High)

70. Debris and Ice Comments:

1

A little debris was left US when the higher flow subsided.

\begin{tabular}{|l|c|c|c|c|c|c|c|c|}
\hline Abutments & $\begin{array}{c}71 . \text { Attack } \\
\angle \text { (BF) }\end{array}$ & $\begin{array}{c}\text { 72. Slope } \angle \\
\text { (Qmax) }\end{array}$ & $\begin{array}{c}\text { 73. Toe } \\
\text { loc. (BF) }\end{array}$ & $\begin{array}{c}\text { 74. Scour } \\
\text { Condition }\end{array}$ & $\begin{array}{c}75 . \text { Scour } \\
\text { depth }\end{array}$ & $\begin{array}{c}\text { 76. Exposure } \\
\text { depth }\end{array}$ & 77. Material & 78. Length \\
\hline LABUT & & - & $\mathbf{9 0}$ & $\mathbf{0}$ & $\mathbf{0}$ & - & - & $\mathbf{9 0 . 0}$ \\
\hline RABUT & $\mathbf{2}$ & $\mathbf{2 0}$ & $\mathbf{9 0}$ & & & $\mathbf{2}$ & $\mathbf{0}$ & $\mathbf{5 2 . 5}$ \\
\hline
\end{tabular}

Pushed: $L B$ or RB

Toe Location (Loc.): 0- even, 1- set back, 2- protrudes

Scour cond.: 0- not evident; 1- evident (comment); 2- footing exposed; 3-undermined footing; 4- piling exposed; 5- settled; 6- failed

Materials: 1- Concrete; 2- Stone masonry or drywall; 3- steel or metal; 4- wood

79. Abutment comments (eg. undermined penetration, unusual scour processes, debris, etc.):

$-$

1

No undermining or exposure.

80. Wingwalls:

Exist? Material? Scour Scour Exposure $\begin{array}{ll}81 . & \\ \text { Angle? Length? }\end{array}$ Condition? depth? depth?

USLWW:

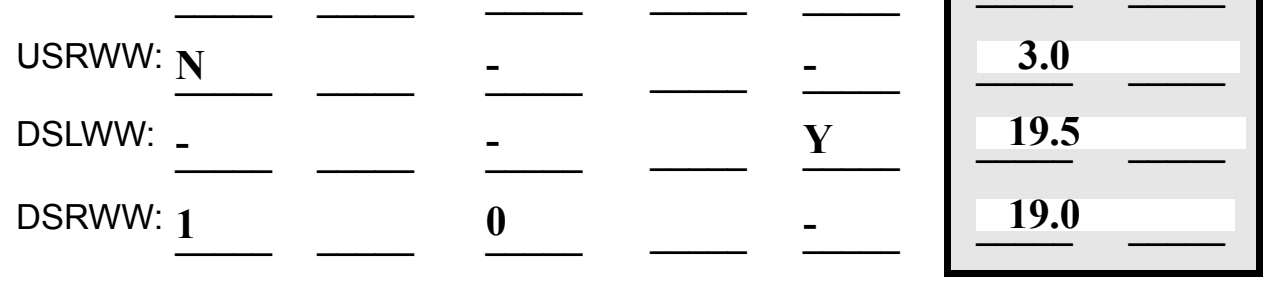

Wingwall materials: 1- Concrete; 2- Stone masonry or drywall; 3- steel or metal; 4- wood

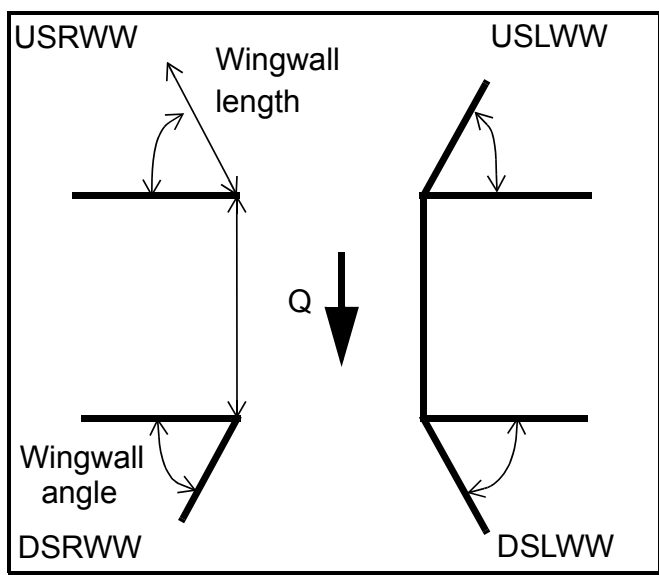

82. Bank / Bridge Protection:

\begin{tabular}{|l|l|l|l|l|l|l|l|l|}
\hline Location & USLWW & USRWW & LABUT & RABUT & LB & RB & DSLWW & DSRWW \\
\hline Type & - & - & $\mathbf{N}$ & - & - & $\mathbf{2}$ & - & $\mathbf{2}$ \\
\hline Condition & $\mathbf{N}$ & - & - & - & - & $\mathbf{1}$ & - & $\mathbf{1}$ \\
\hline Extent & - & - & - & - & $\mathbf{1}$ & $\mathbf{0}$ & $\mathbf{2}$ & - \\
\hline
\end{tabular}

Bank / Bridge protection types: 0- absent; 1- < 12 inches; 2- < 36 inches; 3- < 48 inches; 4- < 60 inches; 
83. Wingwall and protection comments (eg. undermined penetration, unusual scour processes, etc.):

-
-
-
-
-
-
-
-
-

\section{Piers:}

84. Are there piers? Th (Y or if $N$ type ctrl-n pr)

\begin{tabular}{|l|l|l|l|l|l|l|l|}
\hline \multirow{2}{*}{$\begin{array}{l}85 . \\
\text { Pier no. }\end{array}$} & \multicolumn{3}{|c|}{ width (w) feet } & \multicolumn{3}{c|}{ elevation (e) feet } \\
\cline { 2 - 9 } & w1 & w2 & w3 & e@w1 & e@w2 & e@w3 \\
\hline Pier 1 & - & & $\mathbf{8 . 5}$ & - & $\mathbf{8 0 . 0}$ & - \\
\hline Pier 2 & - & - & - & - & - & - \\
\hline Pier 3 & - & - & - & - & - & - \\
\hline Pier 4 & - & - & - & - & - & - \\
\hline
\end{tabular}

\begin{tabular}{|l|l|l|l|l|}
\hline Level 1 Pier Descr. & \multicolumn{1}{|c|}{1} & \multicolumn{1}{|c|}{2} & 3 & \multicolumn{1}{|c|}{} \\
\hline 86. Location (BF) & ere are & ment & & - \\
\hline 87. Type & no & pro- & & - \\
\hline 88. Material & wing & tec- & & - \\
\hline 89. Shape & walls & tion & & - \\
\hline 90. Inclined? & on & is & & - \\
\hline 91. Attack $\angle$ (BF) & the & unde & N & - \\
\hline 92. Pushed & left & rwa- & - & - \\
\hline 93. Length (feet) & - & - & - & - \\
\hline 94. \# of piles & bank & ter. & - & - \\
\hline 95. Cross-members & - & & - & - \\
\hline 96. Scour Condition & The & & - & - \\
\hline 97. Scour depth & right & & - & - \\
\hline 98. Exposure depth & abut & & - & - \\
\hline
\end{tabular}

LFP, LTB, LB, MCL, MCM, MCR, RB, RTB, RFP

1- Solid pier, 2- column, 3- bent

1-Wood; 2- concrete; 3- metal; 4- stone

1- Round; 2- Square; 3- Pointed

Y-yes; $N-$ no

$L B$ or $R B$

0- none; 1- laterals; 2- diagonals; 3- both

0- not evident; 1- evident (comment);

2- footing exposed; 3- piling exposed;

4- undermined footing; 5- settled; 6-failed 
99. Pier comments (eg. undermined penetration, protection and protection extent, unusual scour processes, etc.):

-
-
-
-
-
-
-
-
-
-

100.

\section{E. Downstream Channel Assessment}

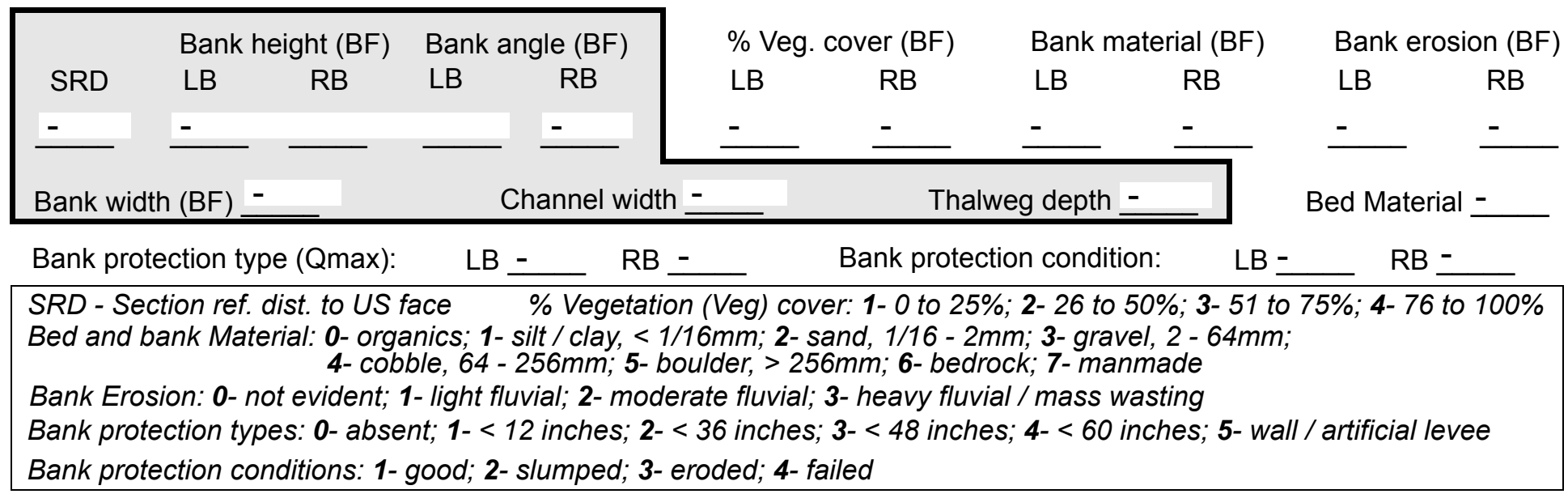

Comments (eg. bank material variation, minor inflows, protection extent, etc.):

-
-
-
-
-
-
-
-

NO PIERS

101. Is a drop structure present? ( $Y$ or $N$, if $N$ type ctrl-n ds)

102. Distance: - feet

103. Drop: __ feet 104. Structure material: (1- steel sheet pile; 2- wood pile; 3- concrete; 4- other)

105. Drop structure comments (eg. downstream scour depth): 
Point bar extent: $\underline{0}$ feet 0

(US, UB, DS) to feet (US, UB, DS)

DS) positio sitioned Bot $\%$ LB to $\mathbf{h}$ $\% \mathrm{RB}$

Material: DS

Point or side bar comments (Circle Point or Side; note additional bars, material variation, status, etc.):

banks show signs of erosion and have no protection within two bridge lengths. There is stone fill placed along the DS left bank starting at 125 feet DS and extending to 150 feet DS. The bed material is loose and it is possible to penetrate as much as 1.5 feet in places along the base of the banks.

Is a cut-bank present? (Y or if $N$ type ctrl- $n$ cb) Where? (LB or $R B)$

Mid-bank distance:

Cut bank extent: feet (US, UB, DS) to feet (US, UB, DS)

Bank damage: (1- eroded and/or creep; 2- slip failure; 3- block failure)

Cut bank comments (eg. additional cut banks, protection condition, etc.):

$\mathbf{N}$

Is channel scour present? (Y or if $N$ type ctrl-n cs)

Mid-scour distance: NO Scour dimensions: Length $\underline{\mathbf{D R O}}$ Width $\underline{\mathbf{P}}$ Depth: STR Positioned UC \%LB to $\underline{\text { TU }} \%$ RB Scour comments (eg. additional scour areas, local scouring process, etc.): RE

Are there major confluences? ( $Y$ or if $N$ type ctrl-n $m c)$

How many?

Confluence 1: Distance $\mathbf{N}$ Enters on (LB or $R B)$

Type (1- perennial; 2- ephemeral)

Confluence 2: Distance Enters on (LB or $R B)$

Type (1-perennial; 2- ephemeral)

Confluence comments (eg. confluence name):

\section{F. Geomorphic Channel Assessment}

107. Stage of reach evolution -

1- Constructed

2- Stable

3- Aggraded

4- Degraded

5- Laterally unstable

6- Vertically and laterally unstable 
108. Evolution comments (Channel evolution not considering bridge effects; See HEC-20, Figure 1 for geomorphic descriptors):

$-$

NO POINT BARS

At 300 feet DS a gravel point bar starts positioned 0\% LB to 50\% RB.

Y

LB

70

25

DS

125

DS

2 


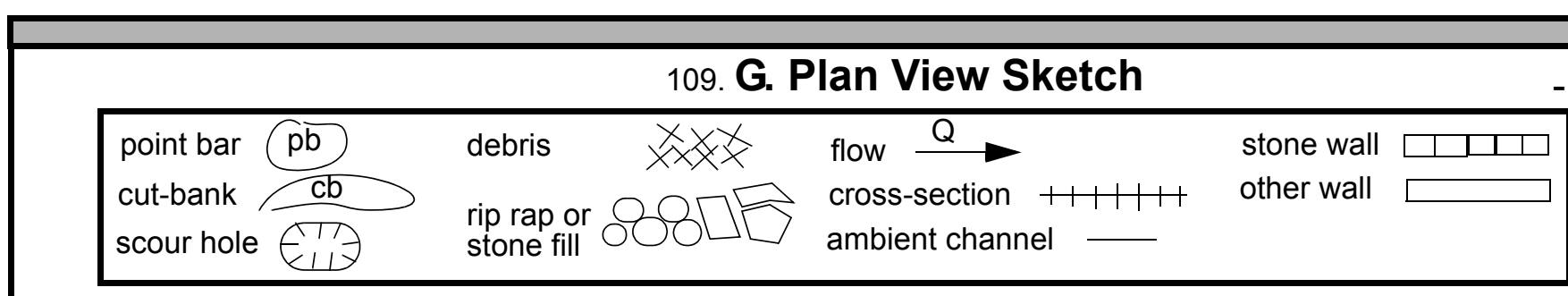


APPENDIX F:

SCOUR COMPUTATIONS 


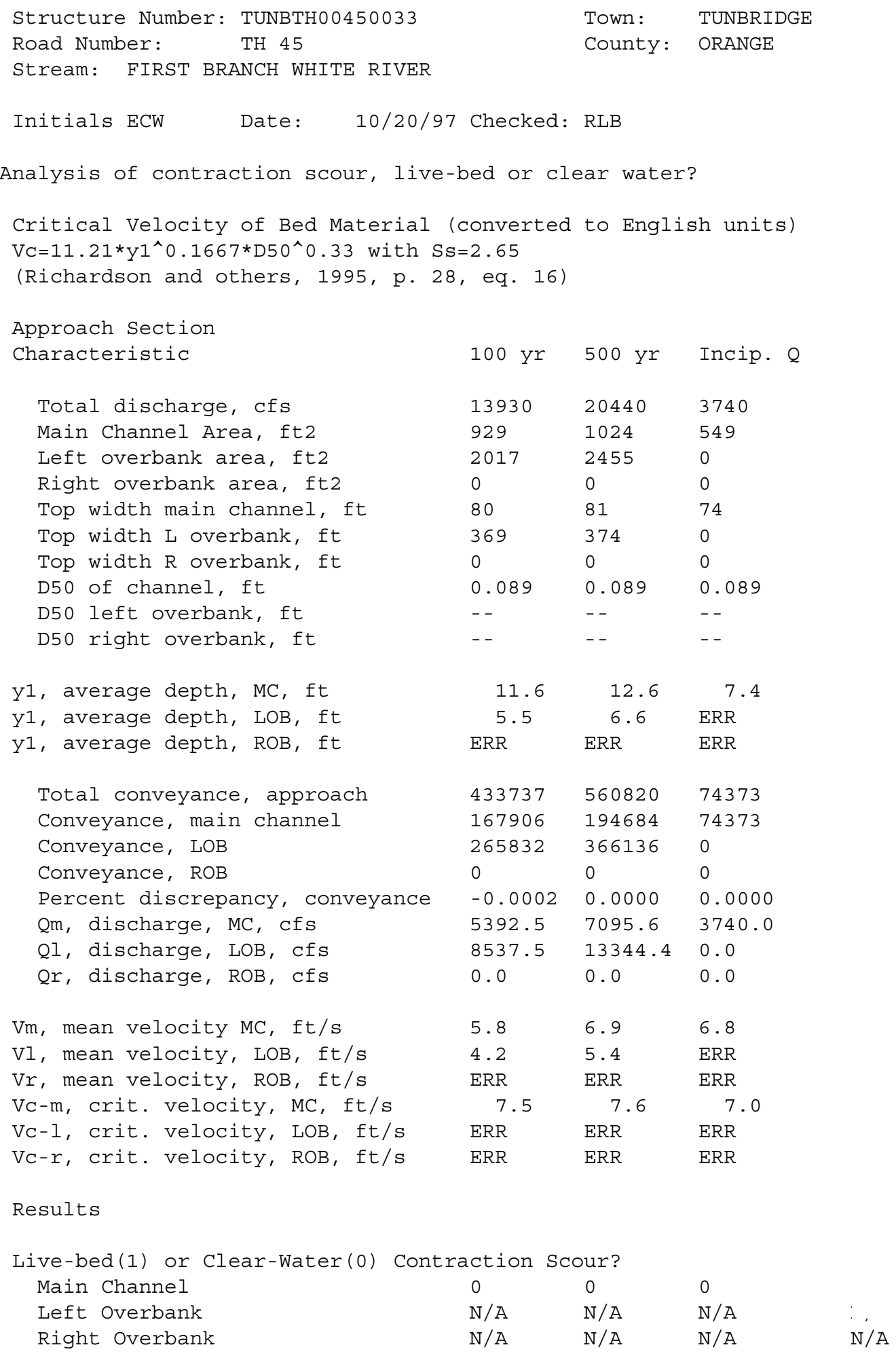


Clear water Contraction Scour in MAIN CHANNEL

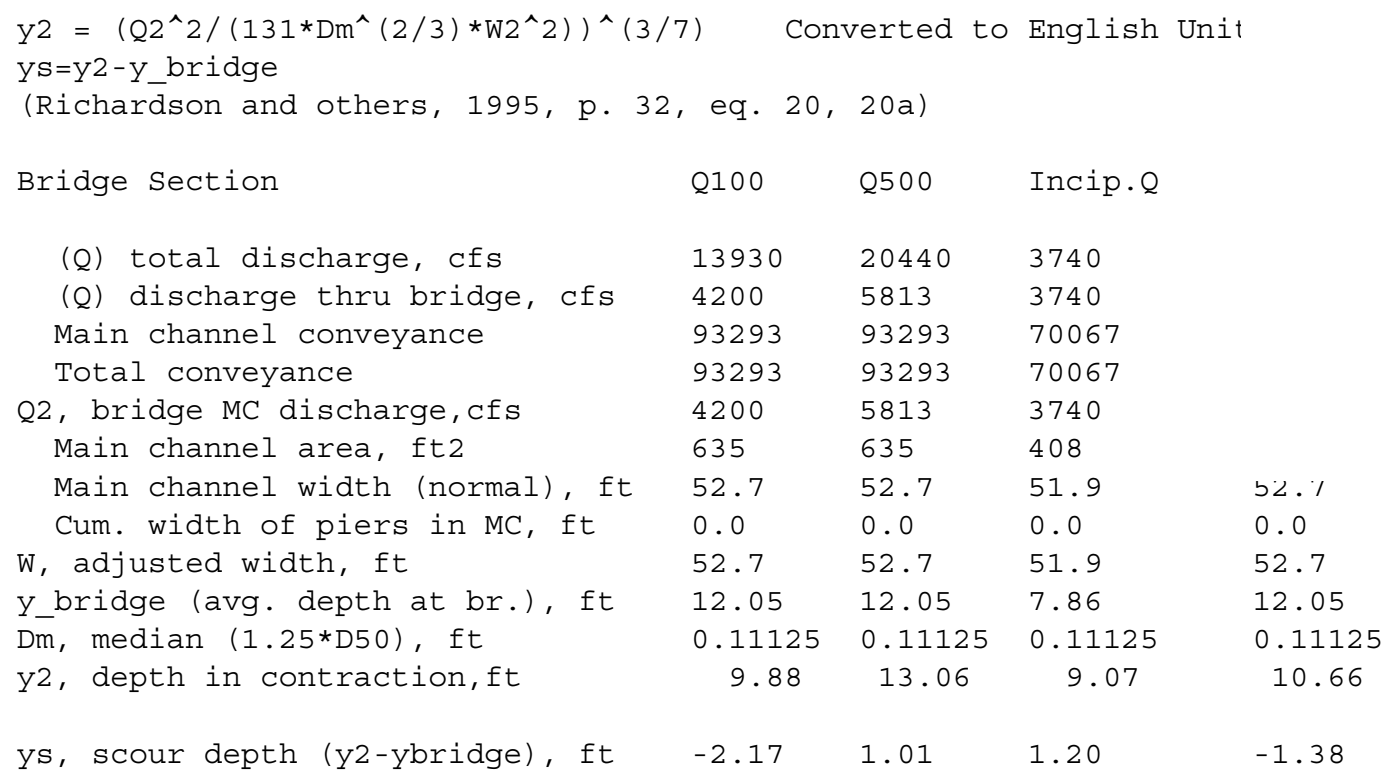

Armoring

$\mathrm{DC}=\left[\left(1.94 * \mathrm{~V}^{\wedge} 2\right) /(5.75 * \log (12.27 * \mathrm{y} / \mathrm{D} 90))^{\wedge} 2\right] /[0.03 *(165-62.4)]$

Depth to Armoring $=3 *(1 / \mathrm{PC}-1)$

(Federal Highway Administration, 1993)

Downstream bridge face property

Q, discharge thru bridge MC, cfs $4200 \quad 5813 \quad 3740$

Main channel area (DS), ft2 $635 \quad 635 \quad 408$

Main channel width (normal), ft $52.7 \quad 52.7 \quad 51.9$

Cum. width of piers, ft $\quad 0.0 \quad 0.0 \quad 0.0$

Adj. main channel width, ft $\quad 52.7 \quad 52.7 \quad 51.9$

$\begin{array}{llll}\text { D90, ft } & 0.2095 & 0.2095 & 0.2095\end{array}$

$\begin{array}{llll}\text { D95, ft } & 0.2525 & 0.2525 & 0.2525\end{array}$

$\begin{array}{lllll}\text { Dc, critical grain size, ft } & 0.1028 & 0.1969 & 0.2259\end{array}$

$\begin{array}{lllll}\text { PC, Decimal percent coarser than DC } 0.424 & 0.122 & 0.080\end{array}$

$\begin{array}{llll}\text { Depth to armoring, ft } & 0.42 & 4.26 & 7.82\end{array}$ 


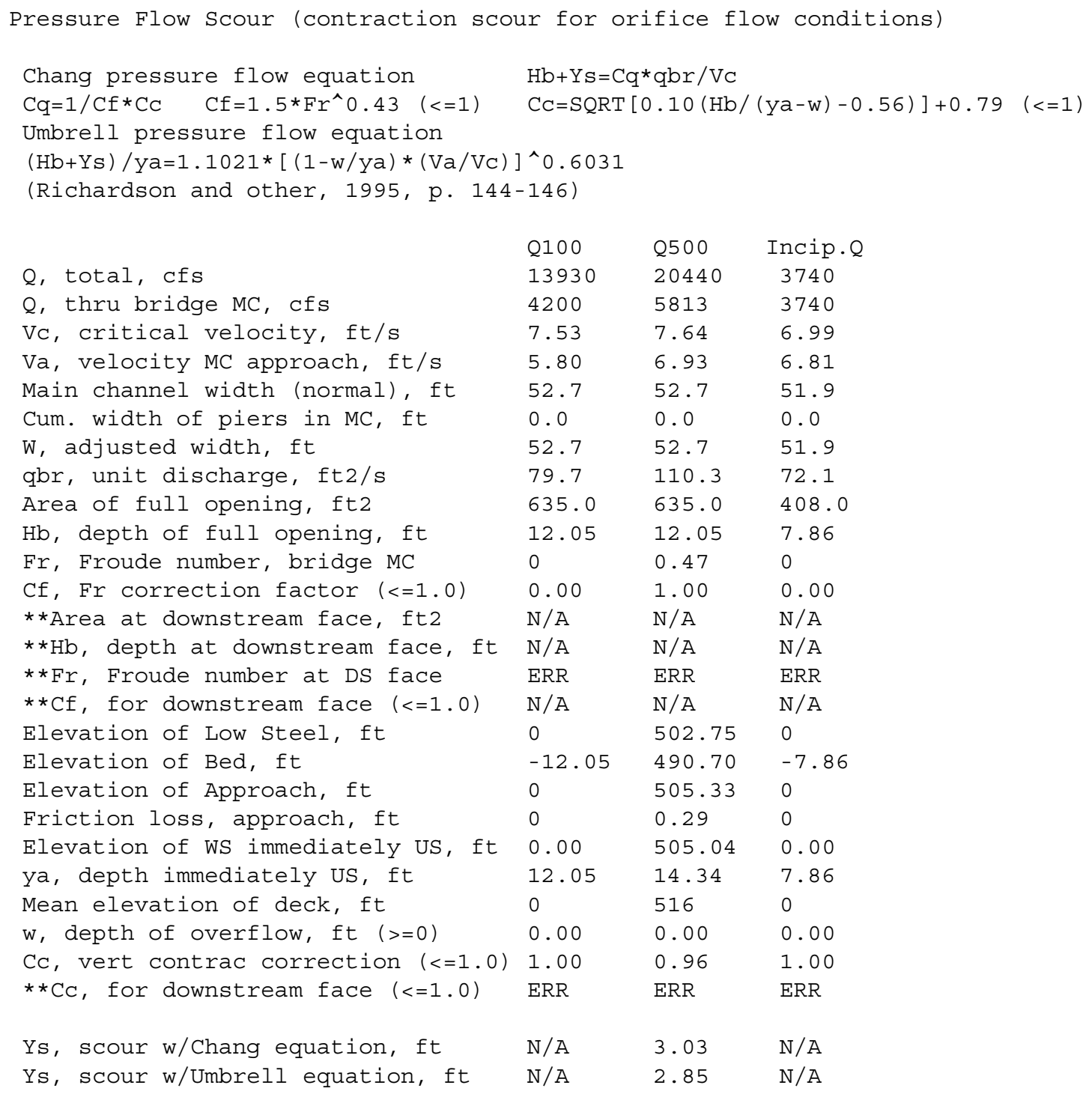




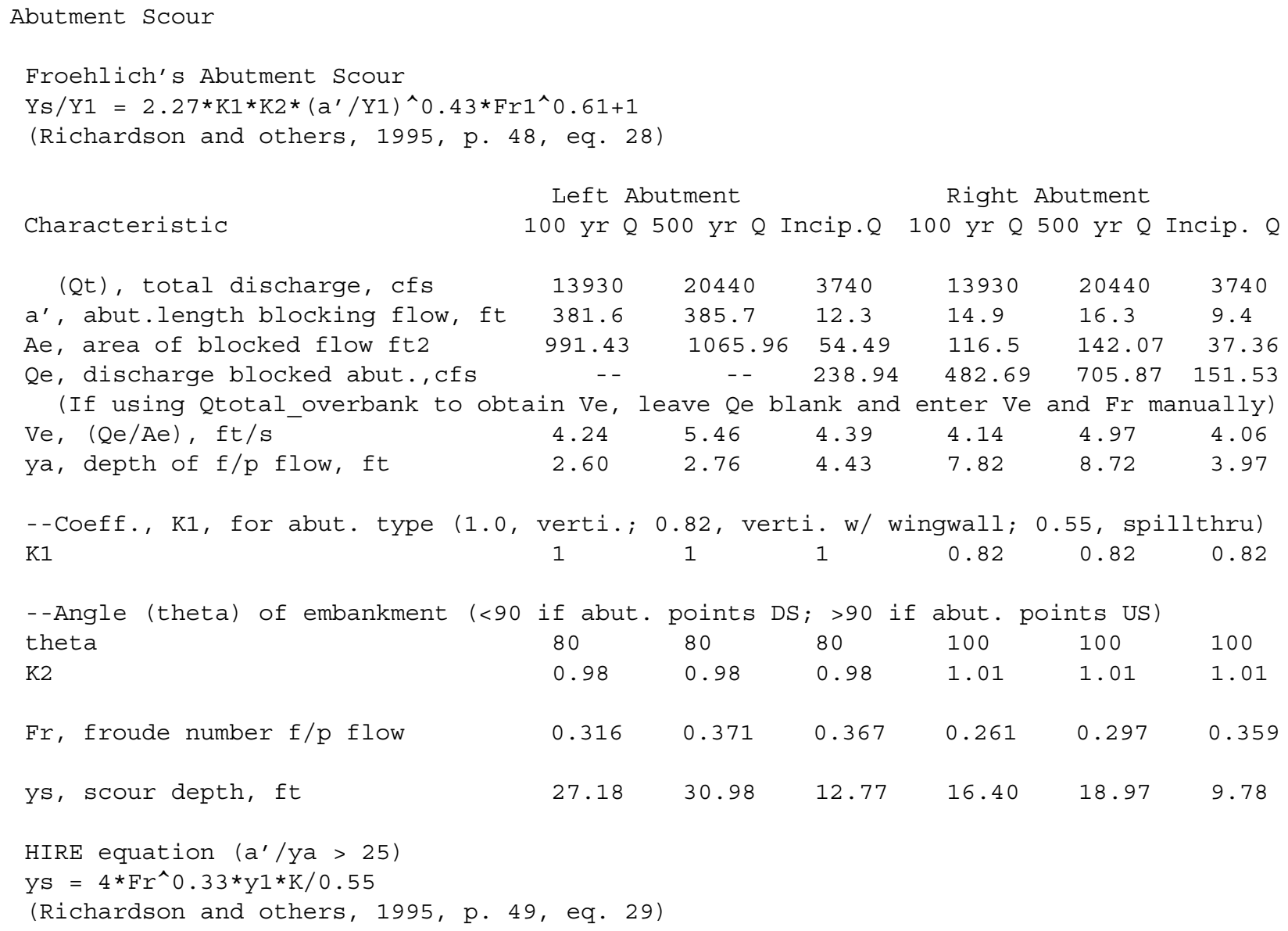




\begin{tabular}{|c|c|c|c|c|c|c|}
\hline a' (abut length blocked, ft) & 381.6 & 385.7 & 12.3 & 14.9 & 16.3 & 9.4 \\
\hline y1 (depth f/p flow, ft) & 2.60 & 2.76 & 4.43 & 7.82 & 8.72 & 3.97 \\
\hline$a^{\prime} / y^{\prime}$ & 146.88 & 139.56 & 2.78 & 1.91 & 1.87 & 2.37 \\
\hline Skew correction (p. 49, fig. 16) & 0.97 & 0.97 & 0.97 & 1.02 & 1.02 & 1.02 \\
\hline Froude no. f/p flow & 0.32 & 0.37 & 0.37 & 0.26 & 0.30 & 0.36 \\
\hline Ys w/ corr. factor $\mathrm{K} 1 / 0.55$ : & 1249 & 14.01 & $E R R$ & $E R R$ & ERR & $F R R$ \\
\hline vertical w/ ww's & 10.24 & 11.49 & ERR & ERR & $\begin{array}{l}\mathrm{ERR} \\
\mathrm{ERR}\end{array}$ & $\begin{array}{l}\mathrm{ERR} \\
\mathrm{ERR}\end{array}$ \\
\hline spill-through & 6.87 & 7.71 & ERR & ERR & ERR & $E R R$ \\
\hline \multicolumn{7}{|l|}{ Abutment riprap Sizing } \\
\hline \multirow{2}{*}{\multicolumn{7}{|c|}{$\begin{array}{l}\text { Isbash Relationship } \\
\mathrm{D} 50=\mathrm{Y}^{\star} \mathrm{K} * \mathrm{Fr} \mathrm{F}^{\wedge} /(\mathrm{Ss}-1) \text { and } \mathrm{D} 50=\mathrm{Y}^{*} \mathrm{~K} *\left(\mathrm{Fr} r^{\wedge} 2\right)^{\wedge} 0.14 /(\mathrm{Ss}-1) \\
\text { (Richardson and others, 1995, p112, eq. 81,82) }\end{array}$}} \\
\hline & & & & & & \\
\hline Characteristic & Q100 & 00 & Incip. Q & Q100 & Q500 & Incip. Q \\
\hline Fr, Froude Number & 0.43 & 0.47 & 0.58 & 0.43 & 0.47 & 0.58 \\
\hline y, depth of flow in bridge, ft & 12.05 & 12.05 & 7.86 & 12.05 & 12.05 & 7.86 \\
\hline \multicolumn{4}{|c|}{ Median stone Diameter for riprap at: left abutment } & right & abutment, & ft \\
\hline Fr<=0.8 (vertical abut.) & 1.38 & 1.65 & 1.63 & 1.38 & 1.65 & 1.63 \\
\hline Fr>0.8 (vertical abut.) & ERR & ERR & ERR & ERR & ERR & ERR \\
\hline
\end{tabular}

